\title{
KÖZLEMÉNYEK
}

\section{A TECHNOLOGICAL APPROACH OF A MICROLITHIC ASSEMBLAGE: THE SITE OF TATA (MIDDLE PALAEOLITHIC, HUNGARY)}

\author{
MARIE-HÉLĖNE MONCEL*
}

\begin{abstract}
The palaeolithic site Tata dated to the oxygen isotopic stage 5 is famous for its very strange lithic assemblage, most of which are smaller than $30 \mathrm{~mm}$. Other OIS 5 sites in Central Europe have yielded microlithic assemblages which are not always related to the specific raw material conditions. The technological analysis of the cores provides new patterns about the technological choice for flaking, which seems to belong to a specific tradition. This hypothesis could be confirmed by the comparative studies of several Middle European microlithic assemblages from OIS 11 to 4-3.
\end{abstract}

\section{Introduction: the technological behaviour of the Neanderthals}

Traditions among Neanderthal groups and their ancestors seem to be everywhere proved in Europe, as in Africa for the first Modern Humans. From 350,000 or 300,000 years old, lithic assemblages show more complex flaking methods. The flake shape is moreover controlled, even if it could be easier to obtain the desired tool shape by retouch rather than by a direct production of a blank of appropriate shape in the cases of a poor quality raw material. Specific and long lasting processing systems appear in Europe, covering large areas, through time and environmental changes. They can give evidence of large technological traditions. Sometimes, within smaller areas, sites show specific behaviours which suggest that they could reflect local traditions related to geographical conditions or human choices.

Lithic assemblage studies, now, show that both technological traditions and activities have now to be considered to explain the characteristics of the abandoned material at a site. Furthermore, the assemblage composition and variability are the result of complex interactions of behaviour, environment and the physical properties of the raw material used. The understanding of human occupation and the nature of the accompanying the lithic assemblages are

\footnotetext{
* MARIE-HÉLÈne MONCEL, Laboratoire de Préhistoire Institut de Paléontologie Humaine. 1 rue René Panhard 75013 Paris France, e-mail: moncel@mnhn.fr
}

thus related to all the site data: type of location, fauna remains and subsistence behaviour, raw material collecting, technological behaviours, types of tools. A repetitive hunting of animals of various ages (prime-age or adults, evidence of intentional prey selection) and traditions of systematic processing of larger quantities of game have been proved, at least from $125 \mathrm{ka}$ to $55 \mathrm{ka}$. These studies, as the lithic ones, often provide evidence of short occupations, or at least of movement of mobile human groups according to the environment, thereby transmitting knowledge over generations.

Use-wear-analysis and the reduction sequence studies (from raw material collecting to flaking and tools discarding; "chaîne opératoire") indicate that the Neanderthal abilities were both numerous and varied, through technological traditions, especially for the stone work. However, some discoveries indicate that bones could be used sometimes, due to a lack of large stone blocks or by tradition. ${ }^{1}$ Wood is also a raw material, as the discoveries of Schöningen, Lehringen in Germany, Clacton in Great Britain or Abri Romani in Italy attest. ${ }^{2}$ They suggest a technological world much larger that we could assume by only stone studies. ${ }^{3}$ Nevertheless, a large production of blanks seems, above all, only obtained

1 For example, Castel di Guido, Fontana Ranuccio or Bilzingsleben; MANIA et al., 1980; MANIA, 1995; RADMILLI-BOSCHIAN, 1996; MANIA, 1998

2 OaKley et al. 1977; Carbonell-Castro-Curel 1992; Thieme 1997-1998; MANIA 1998.

3 Koller et al. 2001. 
by a stone processing system, even numerous wooden tools could successively be prepared according to the wood resources and the needs.

\section{The microlithic assemblages over time}

For the last 40 years, sites from Central Europe yielded a great number of microlithic assemblages. Most of them date to the OIS 5 (Eemian) or to the beginning of the last glacial period, frequently associated to travertine deposits. The scarce human remains, brain cast in Gànovce and teeth in Taubach, show that these original industries have been made by Neanderthals. ${ }^{4}$ These microlithic assemblages, located in the same geographical area (small plains and basins within Central Europe), are present in Taubach, Weimar and Stuttgart-Bad Cannstatt in Germany; Kůlna (couche 11), from Czech Republic, Gànovce, Bojnice III, Hôrka (Slovakia), Tata in the Carpathian basin, Wroclaw, Hallena Street from Poland. ${ }^{5}$

The greatest frequency of such assemblages during the last interglacial, beginning around $125 \mathrm{ka}$, suggested to D. Collins in 1969, then to K. Valoch, the idea of creating a cultural group named Taubachian in Central Europe, from Taubach in Germany ${ }^{6}$ to focus on the variability of these numerous assemblages dating for most of them to the OIS 5 and 4 (more than 40 listed sites). Although the different cultural names, used by researchers, such as Kiik-Koba Micromousterian, Micoquian Micromousterian or Pontinian in Italy, are often based on tool types or on geographical areas, technological analysis brings evidence of various traditions inside these microlithic assemblages, perhaps related to regional trends. ${ }^{7}$ Associated to various fauna remains, these assemblages also indicate that different environments could have been exploited through this kind of artefacts, on different raw materials.

This phenomenon is actually frequent in both time and space. Microlithic industries exist in old periods, even if they remain rare (Vértesszőlős, Bilzingsleben, Trzebnica in Central Europe) ${ }^{8}$ in the easternmost part of Eastern Europe, Central Asia or the Near East. ${ }^{9}$ Some of these sites, for example in Bilzingsleben (Germany) and Vértesszőlős (Hungary), are also located in travertine. The question of an association with a specific location, linked to a specific way of life, requiring a specific technology, has been consequently asked, even if a better preservation of the archaeological remains inside travertine deposits undoubtedly sheds a distorted light on this type of settlement.

The microlithic assemblages dating to the OIS 5 and 4 in Central Europe

The term "Taubachian" does not seem to describe in the best way all the microlithic assemblages, dating to the OIS 5 and 4, from this part of Europe and cannot be employed to designate a single lithic entity. The Taubach assemblage is not the best example of a microlithic assemblage..$^{10}$ However, largely described by K. Valoch in Kůlna (the Czech Republic), the microlithic industries gather some common characteristics as the use of small pebbles in various rocks, contributing to a microlithic assemblage, the "nonLevallois" technology in most cases, the average size of the flakes of $3 \mathrm{~cm}$ or less, a lot of broken flakes. ${ }^{11}$ The flat retouch is also lacking, as are the bifacial tools. Side-scrapers, denticulates and notches are prevalent, associated with microchoppers. Bones often show numerous retouches of compressors. ${ }^{12}$

These assemblages are often related to hot water springs (but also to caves and river banks), and the animal remains especially belong to one or two great herbivores (bovines, horses), associated with smaller animals in some cases. Among the fauna, there are also remains of large mammals such as elephants and rhinoceros. In some assemblages, these species are quite numerous, for example, Cerous elaphus, Dicerorhinus mercki (70\% young) and Bison priscus in Taubach in a mixed forest context. ${ }^{13}$ Dicerorhinus mercki and Elephas antiquus in Gànovce. ${ }^{14}$ In Tata, the Mammoth is the dominant species.
4 LoZeK 1954; ProzeK 1958; VAloch 1996.

5 VÉRTES et al. 1964; GÁBORI-CSÁNK 1968; VALOCH 1967, 1977, 1984, 1996; BÁNESZ 1991; WAGNER 1982; KAMINSKA et al. 1993; WISNIEWSKI 2001. Fig. 1.

6 VALOCH 1977, 1984.

GÁbORI 1976; STEPANCHUK 1994; KuHN 1995; LiOUbine 1998.

BurdukiEWICZ et al. 1979, 1994; MANIA 1988a; MANIA et al 1980; Dobosi 1983a, 1988; BuRduKIEWICZ 1993.

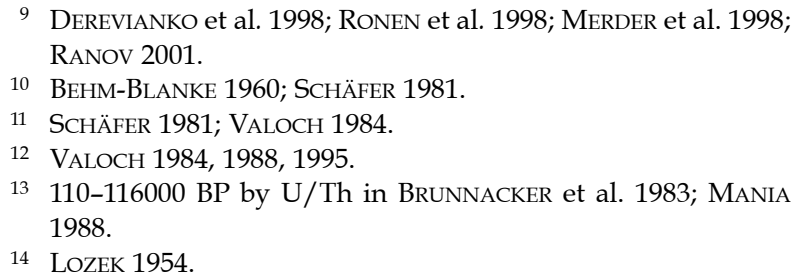




\section{The site of Tata}

This open-air site is located near Budapest (70 $\mathrm{km}$ west-north-west) in Hungary, in the northeastern part of Transdanubia and in a depression separating two areas of the Transdanubian range (Fig. 1). Humans settled in a calcareous tuff basin besides temperate water springs, not far from raw material sources. This site has been mainly excavated by László Vértes in 1958 and 1959 on more than a $70 \mathrm{~m}^{2}$ in surface. ${ }^{15} \mathrm{~A}$ main human settlement has been discovered within lenses of loess, $1 \mathrm{~m}$ or less in thickness, within accumulation of travertine.

The fauna remains are few, mostly composed of Ursus arctos and Mammoths (especially 6 young individuals), associated with some remains of various herbivores as horses. ${ }^{16}$ The prime-age of the Mammoths could indicate a settlement during the summer. On the contrary, the rich lithic assemblage (more than 20,000 artefacts) can indicate remains of flaking areas or subsistence areas.

In 1964, L. Vértes dated the settlement to an interstadial period belonging to the beginning of Würm (Brørup). $\mathrm{A}^{14} \mathrm{C}$ dating on a charcoal sam- ple confirmed the first age hypothesis with a date of $55,000 \pm 2,500$ B.P. However, the palaeontological and malacological studies place the level back to the end of the last interglacial. These distorted results have been explained by L. Vértes by the water springs related to the site. The first U/Th dating agrees more with the palaeontological hypothesis. The human occupation could be dated from $70,000 \pm 2,000$ B.P. to $116,000 \pm 1,600$ B.P., from the end of the last interglacial to the beginning of the last glacial period. ${ }^{17}$

The two most famous artefacts from this site are a "chouringa" carved in a fragment of a mammoth tooth (determined by L. Vértes a cult object from Australian Aborigines) and an "amulet" with an engraved cross made on a polished nummulite fossil. The tooth fragment seems to have been carefully separated from the mammoth molar tooth, then shaped, bevelled, and coloured in red by rubbing with ochre. Ochre remains have also been discovered inside the site.

L. Vértes connected the assemblage to Middle Palaeolithic pebble industries with affinity to the Quina type, close to other sites such as Kiskevély

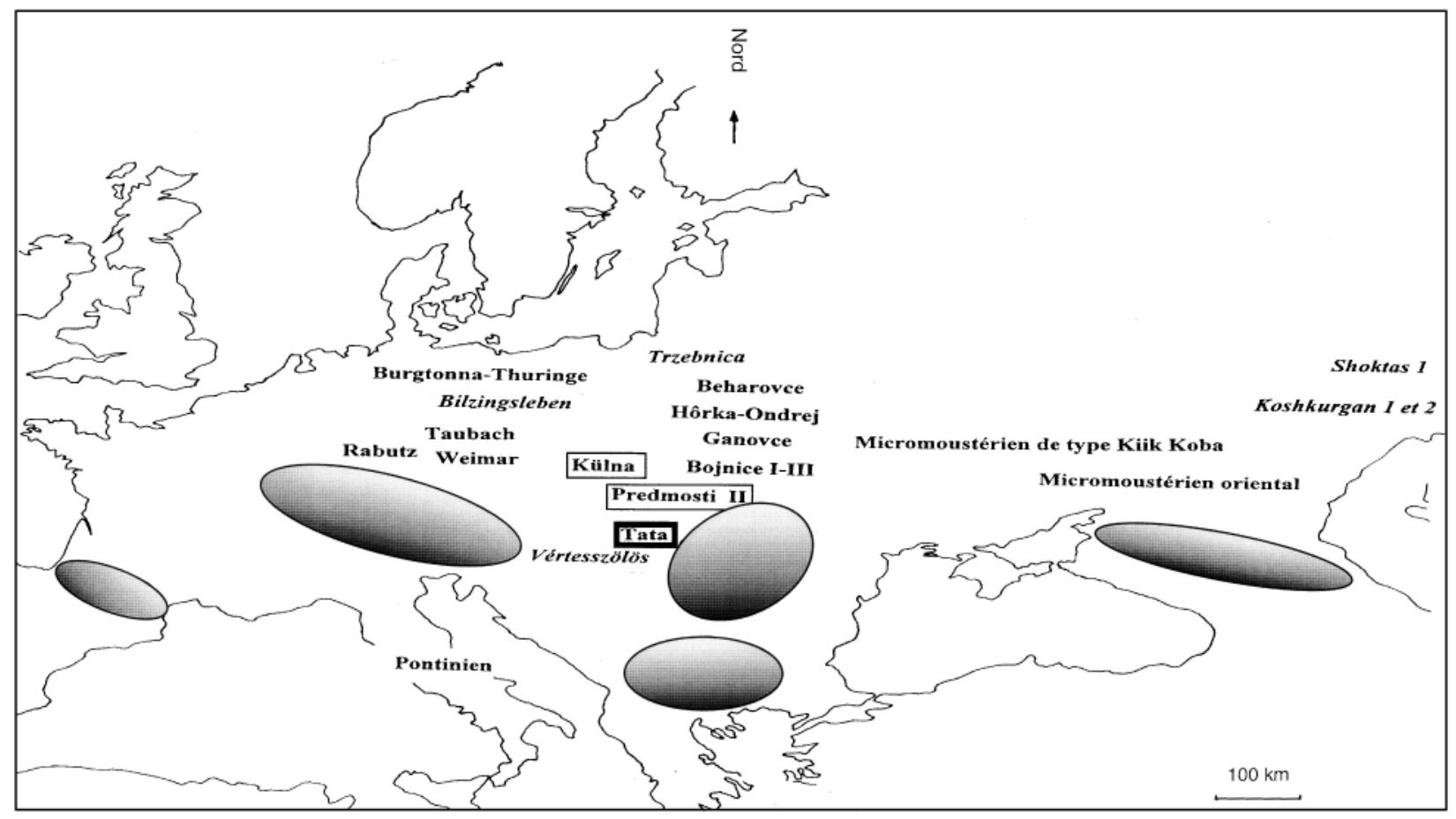

Fig. 1. Tata among microlithic sites in Central Europe

1. kép. Tata és Közép-Európa mikrolitikus lelőhelyei

15 VÉRTES et al. 1964.

16 VÉRTES et al. 1964; PATOU-MATHIS 1999.

17 SCHWARCZ-SKOFLEK 1982. 
cave, Szelim cave and Csákvár cave in Hungary. ${ }^{18}$ The pebble tools and the pebbles are less numerous. Most of the activities are related to flaking. Silicites (flint and chert pebbles) and radiolarites make up $88 \%$ of the artefacts, associated with quartzite $(11 \%)$ and some other and rare stones. Quartzite is more among the chip materials. ${ }^{19}$ The geological studies show a local collecting, in the Tertiary gravel beds near the site. They also indicate that the small pebbles used by humans were arbitrarily selected. ${ }^{20}$ Around $150 \mathrm{~kg}$ of flint or chert have been brought by humans to the settlement.

More than $40 \%$ of the artefacts bear used marks and around $10 \%$ are retouched. Scrapers dominate the tool kit (52\% of 2300 tools) and various types can be described (lateral scrapers, converged scrapers, double scrapers, bifacial scrapers, scrapers on pebble segments, denticulated scrapers, backed scrapers). Between 10 and $25 \%$ of the retouches are bifacial, according to the scraper types. Several kinds of points are also present such as Tayac points, Handspitzen and Blattspitzen points, Faustkeil points. End-scrapers, borers and backed knives are few, associated with some disc tools, "raclettes" and "tranchets". Specific Tata scrapers have been identified, with a retouch on the ventral face of the flake, similar to the shaping of a chopping-tool. Associated with the stone artefacts, numerous bones with crushed marks have been described by L. Vértes.

\section{The studied assemblage}

The methodological approach is based on the technological analysis of all the artefacts in order to understand the reduction sequences used by humans, and especially the processing systems. These are more suitable for characterising a tradition than the typology and for recognising what kinds of blanks humans produced and what methods they followed. The artefacts have been grouped, according to their technological background and the type of raw material.

The Tata lithic assemblage is composed of different artefact groups (Table 2). The most numerous is undoubtedly related to the debitage with almost 20,000 flakes. Among them, some are retouched, while others are left rough. The pebble tools and the entire or broken pebbles are very rare, compared to the number of flakes and cores.
The proportion of rough flakes bearing use traces allows us to conclude that a large number of them could have been used without being retouched. Cores show retouches, too. Consequently, the lithic assemblage may be grouped in five main functional groups: entire and broken pebbles, pebble tools, rough flakes, flake tools and tools on cores. By this fact, the main activity of the toolmakers can be considered as the debitage, associated with a very secondary activity of shaping. All the processing system is represented in the assemblage, with the first cortical removals, cortical flakes, flakes without cortex, cores and chunks. The debitage took place in the living area.

\section{The entire pebbles: raw material stock or hammer} stones?

79 pebbles have been analysed. Some of them are broken (half or quarter pebbles). All these pebbles belong to the different rocks used by humans but the rarest ones such as quartzite, quartz or limestone are proportionately more used than the silicites. The collecting concerns a large variety of pebble types. Most of the pebbles are elongated, narrow and flat, but both oval pebbles and quadrangular pebbles have also been collected. The sizes, from 10 to $135 \mathrm{~mm}$, attest that large pebbles were yet available near the site, even if the 50-60 mm size is the most frequent (Fig. 2). In sum, the smallest and largest pebbles are very scarce within this assemblage, and they have been used for the shaping for the former or the flaking for the latter. The pebble thickness is small, between 10 and $20 \mathrm{~mm}$ in most cases and some of the pebbles are very flat (around 22 items), looking like discs or pucks. None of them bear use marks, like for most of the entire or broken pebbles. The reason of their collecting is consequently still unknown. ${ }^{21}$ When there are use marks, they look like percussion marks located on one of the pebble ends. Pebbles would be hammers, explaining the main choice of grained stones.

\section{The pebble tools: evidence of a limited shaping}

The artefacts considered as pebble tools are less numerous and some of them can be considered as cores and tools. The removals are deep, from different striking platforms and use marks are

21 Suggestions of stone compressors; MONCEL-SVOBODA 1998.

\footnotetext{
18 VÉRTES et al. 1964

19 Doвosi $1983 \mathrm{~b}$

20 Dobosi 2000.
} 
Table 1

The studied lithic assemblage from Tata

\begin{tabular}{|c|c|c|c|c|c|c|}
\hline Site & Entire pebbles & Pebble tools & Cores & $\begin{array}{l}\text { Flakes and } \\
\text { fragments }\end{array}$ & $\%$ tools & Total \\
\hline Tata & 79 & 100 & 268 & $<20,000$ & $<10 \%$ & $>20,000$ \\
\hline
\end{tabular}

The kinds of "functional artefacts"

Table 2

The "functional blanks" used by humans in Tata

\begin{tabular}{llll}
\hline Types of products & Frequency & Size & Main characteristics \\
\hline $\begin{array}{lll}\text { Entire and broken pebbles } \\
\mathrm{n}=79\end{array}$ & $\begin{array}{l}10-135 \mathrm{~mm} \\
(50-60 \mathrm{~mm})\end{array}$ & $\begin{array}{l}\text { quartzite, quartz and limestone }>\text { elongated, narrow and } \\
\text { flat pebbles, some flat pebbles (discs) }\end{array}$ \\
$\begin{array}{lll}\text { Pebble tools } \\
\text { Rough flaking products }\end{array}$ & $\mathrm{n}=<20,000$ & $\begin{array}{l}10-30 \mathrm{~mm} \\
\text { bladelets }(10 \%)\end{array}$ & $\begin{array}{l}\text { tools or cores } \\
\text { and thick platform on the flakes }\end{array}$ \\
Tools on flaking products & $<10 \%$ & $15-30 \mathrm{~mm}$ & $\begin{array}{l}\text { points on triangular flakes, side-scrapers with a thin } \\
\text { retouch, bifacial and flat retouches }(10 \%)\end{array}$ \\
Retouched cores & $<5 \%$ & $20-30 \mathrm{~mm}$ & backed cores, tool shaping integrated in the flaking process \\
\hline
\end{tabular}

lacking on the edge. However, some of them can be tools or both cores and tools, because of the removal organisation and the pebble tool shape. The removal number is in general low, more when the shaping is bifacial (around $50 \%$ of the cases). Each face is worked independently, in one case with an alternate shaping. The bifacial shaping is usually partial, perhaps due to a specific pebble shape requiring a specific work. The removal sizes do not depend on the size or the shape of the pebble (Fig. 3). The removal location on the pebble is also various, on the narrowest or the longest edge. In some cases, two edges are worked, resulting in lateral and convergent pebble tools. The cutting edge is convex or irregular, rather short, sometimes covering more than three quarters of the pebble periphery.

The raw materials are various, in the same proportions as for all the assemblage. Pebbles are often oval and sometimes very flat. Some flat pebble tools are sometimes on slab fragments. Most of them are between 30 and $50 \mathrm{~mm}$ in length (Fig. 4). A few measure less than $30 \mathrm{~mm}$ or more than $60 \mathrm{~mm}$.

\section{The flaking products}

As a result, the production is diversified. Almost $70 \%$ of the flakes are in flint or silicite stones, associated with quartzite and some quartz. Half of the flakes measure less than $30 \mathrm{~mm}$ and around $10 \%$ less than $10 \mathrm{~mm}$ (Fig. 5). However, the size can reach $80 \mathrm{~mm}$ for some cortical flakes. Even tough the production is microlithic, some big pebbles have thus been worked. A small part of the assemblage is composed of elongated flakes or bladelets, and an the hypothesis of intentional debitage of elongated products cannot be discarded considering that 25 to $30 \%$ of the artefacts are laminar flakes, blades and bladelets. The blades and the bladelets total around $10 \%$ of the artefacts. The longest ones measure $60 \mathrm{~mm}$. The bladelet size is often 15-20 $\mathrm{mm}$ long, $5 \mathrm{~mm}$ wide and $2 \mathrm{~mm}$ thick.

A large quantity of the flakes are thick, short and backed (around 50\% backed flakes), with or without cortical patches. The flake section is not symmetric and these flakes have in general a large and thick platform. Some of them are pebble slices, truncating all the pebble section. The core-reduction begins without preparation of the pebbles, using the cortical flat sides. The high proportion of backed flakes provides evidence of a large use of the core or pebble edges to guide the removals. Generally, the platform is flat. Dihedral and still more facetted platforms are rare. The proportion of cortical flakes is high, indicating a short cortex removal stage within 

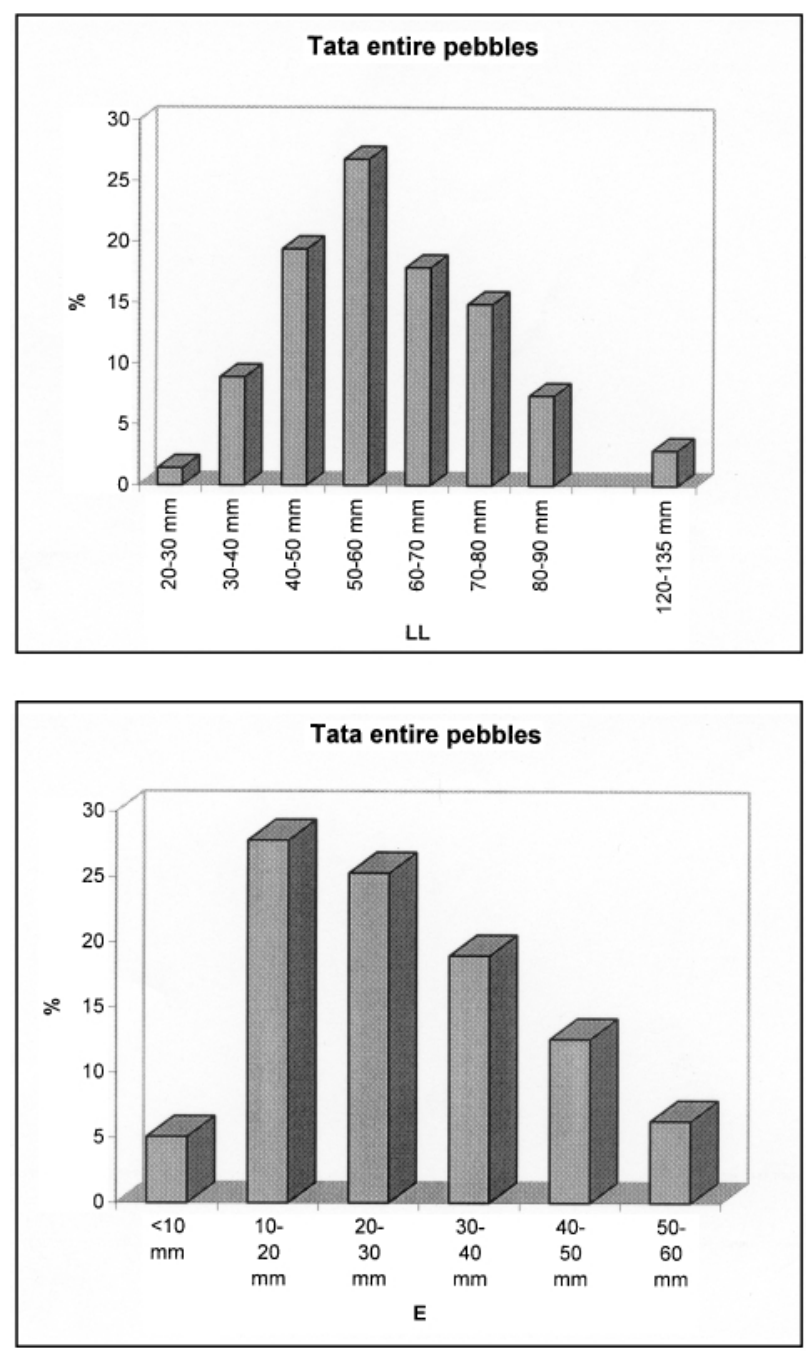

Fig. 2. Length and thickness of the entire pebbles from Tata

2. kép. Tata, ép kavicsok hosszúsági-vastagsági adatai

the knapping. In some cases, the back is in distal location. In other cases, the removal organisation and the flake section prove that the flaking surface is totally truncated by a large scar. When the products are thin, they are without a back in most cases (Fig. 6).

The flake morphology is various: trapezoidal, oval and triangular. The location of the sharp cutting edge available depends on this morphology. The cutting edge of the short flakes or the elongated flakes is located all around. The edge of the backed flakes is opposite to the back. When the platform is large and thick, the longest cutting edge is either on the distal part or on the lateral part of the blank, according to its morphology.

The removals are unipolar, bipolar, crossed or centripetal, providing diversified flake sections. The thin flakes are often related to the unipolar or bipolar patterns. The thick flakes and the backed flakes are rather produced by crossed or centripetal debitage, on cores with two opposite surfaces, two orthogonal surfaces or multidirectional surfaces.

The proportion of thin flakes is higher for flint than for quartzite and the good quality of the raw material could explain this difference. However, all the technical patterns are the same for the two main rock groups. It is possible that the quartzite often required a slice debitage unlike the flint. It is also possible that the toolmakers sometimes used a different processing system according to the two raw materials, for different reasons, not only due to the quality of the rock, but also their ability.

\section{The flake tools and the retouched cores}

Around $10 \%$ of the debitage bear retouches. Most of them are scrapers (65\%) of a large variety, according to the F. Bordes classification. ${ }^{22}$ The most numerous scrapers are simple. $10 \%$ are points and 5\% Upper Palaeolithic tools (endscrapers, borers and burins). In another point of view, the analysis of the retouch location, according to the morphology and the section of the blanks, brings evidence of some choices and, without doubt, offers some explanations of the flake's variety (Fig. 7).

The retouch types on the scrapers are diverse: marginal, ordinary, more or less steep or invasive. It is direct in most cases. All of this depends on the section and morphology of the flake, the most convex surface being worked first. Some inverse retouches are flat and invasive, however, not related to the section but located to some specific parts of the flakes. For example, they are on the butt or along the back of the artefact. They make the blank thinner and could be considered as a shaping. The microwear analyses show that the retouched areas are not always the used ones.

The products from the successive stages of the processing system can be selected. The toolmakers are not very strict about the blanks, since some broken flakes have been retouched after breaking.

The retouched edge is in general the longest of the flake, opposite to the back when present. This edge may be transversal (in this case, the platform looks like a back) or lateral (Table 3). The whole edge is frequently retouched. In sum, a long cutting edge seems to be the first criterion

22 BORDES 1984. 

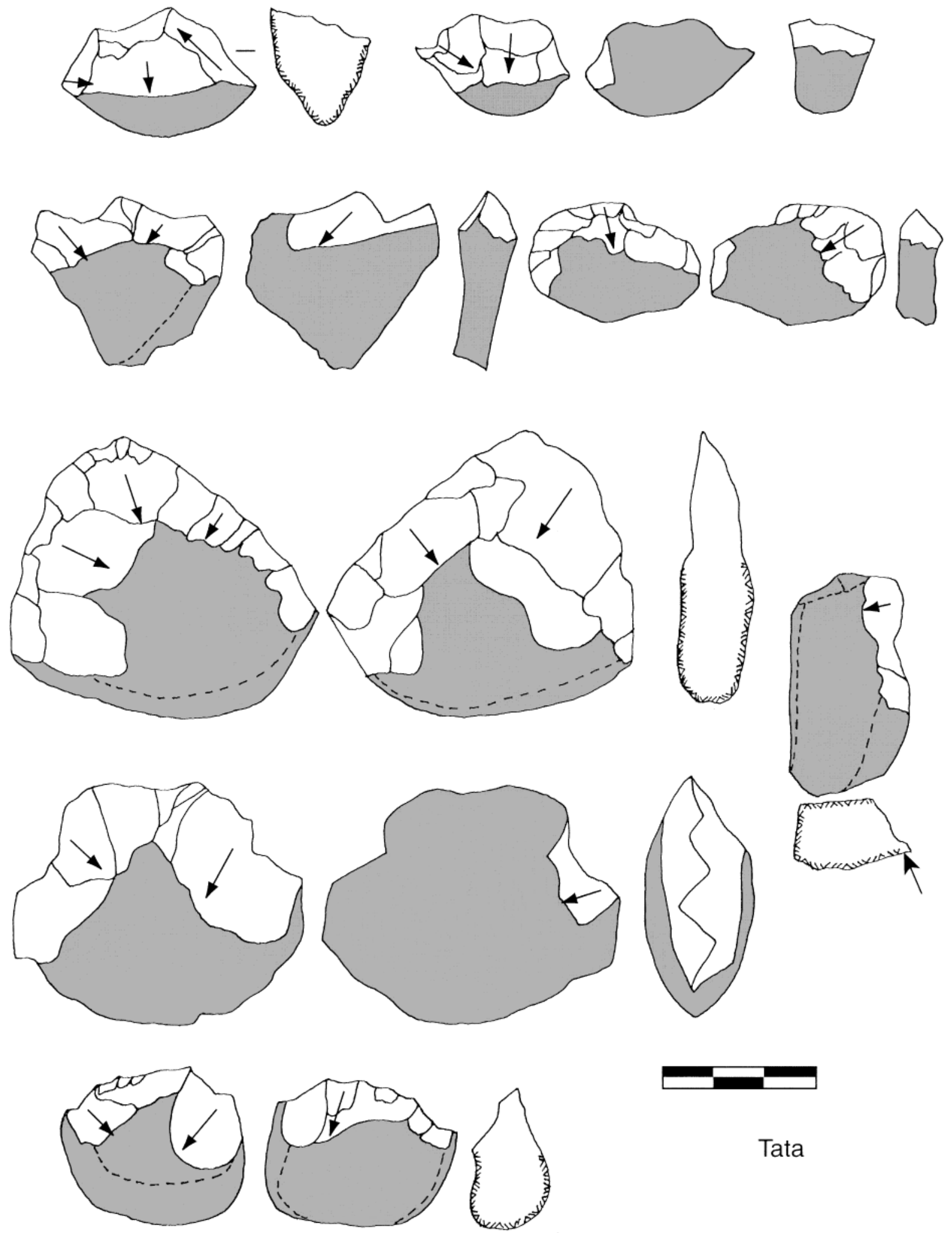

Tata

Fig. 3. Pebble tools: tools or cores?

3. kép. Kavicseszközök: eszközök vagy magkövek? 
Table 3

Flake morphology and location of the retouch

\begin{tabular}{|c|c|c|c|c|c|c|c|c|}
\hline $\begin{array}{l}\text { Blank } \\
\text { retouch }\end{array}$ & $\begin{array}{l}\text { Oval- } \\
\text { rectangular } \\
+ \text { back }\end{array}$ & $\begin{array}{l}\text { Oval- } \\
\text { rectangular }\end{array}$ & $\begin{array}{l}\text { Triangular } \\
+ \text { back }\end{array}$ & Triangular & Square & $\begin{array}{l}\text { First } \\
\text { cortical }\end{array}$ & Core & Broken \\
\hline Lateral & 46 & 39 & 74 & 37 & 41 & 51 & 21 & 5 \\
\hline $\begin{array}{l}\text { Transversal } \\
\text { Lateral + } \\
\text { transversal }\end{array}$ & 7 & 33 & 28 & 7 & 9 & 23 & 2 & \\
\hline Butt & 1 & 2 & & & & 13 & & \\
\hline Convergent & 15 & 9 & 39 & 53 & 10 & 30 & 3 & 3 \\
\hline Two edges & 5 & 14 & 1 & 4 & 3 & 8 & 1 & \\
\hline Three edges & 1 & 14 & & 2 & & 9 & & \\
\hline Back & & & 2 & 3 & 1 & & & \\
\hline Point & & & & 1 & & 1 & & \\
\hline Oblique & 10 & 4 & 10 & 4 & 2 & 9 & 1 & \\
\hline Total & 85 & 115 & 154 & 74 & 66 & 144 & 29 & 8 \\
\hline
\end{tabular}

Total sample: 675

of choice to proceed to retouches. These ones never change the flake shape. Consequently, the flake morphology is a good indicator of what was researched by the toolmakers for the activities. In contrast, the elongated blanks seem to be less retouched than the other blanks, and certainly used rough.

The same kind of behaviour is observed for the points. They are on triangular flakes (with a large and wide base), and the retouched area can be partial or only on one edge. In this case, converging tools actually could group around 30\% of the tool kit. The points are not always symmetric, according to the location of the point on the flake ("pointes d'axe", "pointes déjetées"). The pointed end is independently retouched, and is not only the combination of two retouched edges. Some of them are broken or crushed, with some broken extremities inside the assemblage. Around $10 \%$ of the tools, and especially the

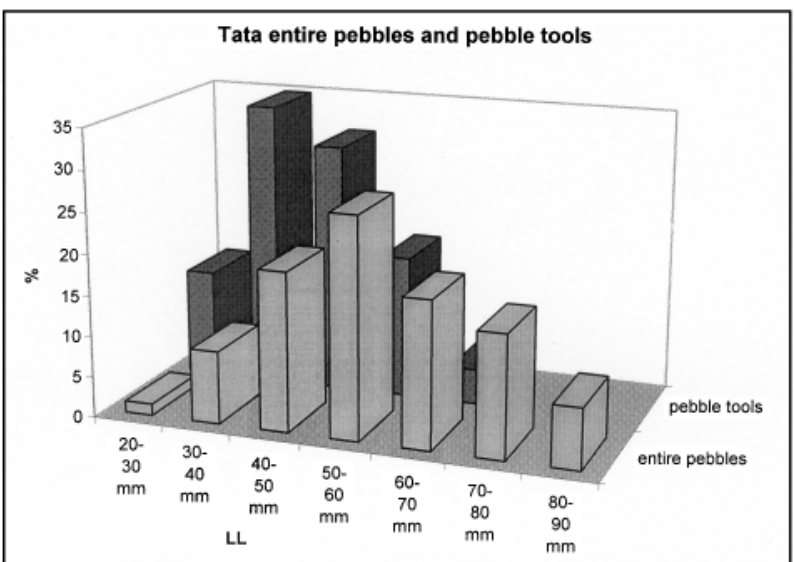

Fig. 4. Length of the entire pebbles and pebble tools 4. kép. Ép kavicsok és kavicseszközök hosszméretei points, bear bifacial retouches. On one face, the retouch is flat, while on the other, the most convex one, it is abrupt. They look like small handaxes whose proportion and variety have given the originality of Tata in comparison to other microlithic assemblages.
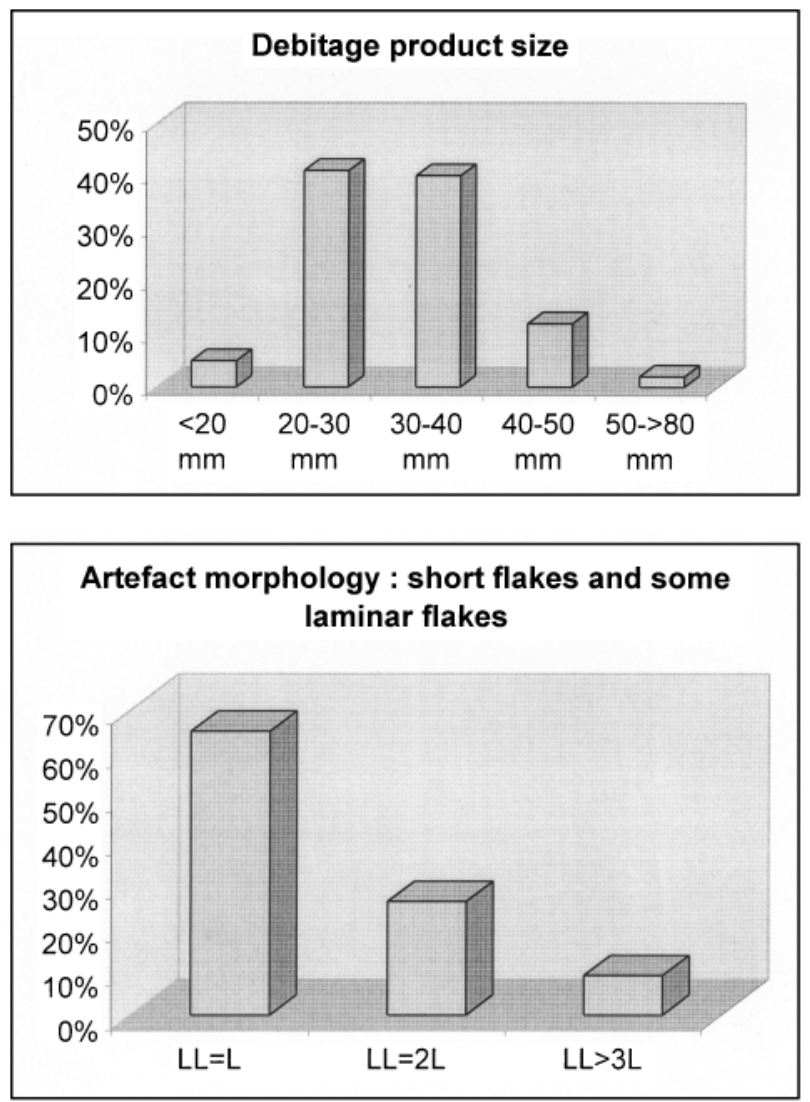

Fig. 5. Tata, debitage product size and artefact morphology 5. kép. Tata, szilánkméretek és az eszközök morfológiája 
The size of the retouched flakes is between 10 and $35 \mathrm{~mm}$, but most of them are between 15 and $30 \mathrm{~mm}$, the smallest and the biggest flakes being mostly used rough (Table 4). It is the same for the tool thickness. The very thin flakes are rarely retouched and the high proportion of small cortical flakes among the retouched blanks could be explained by the largest thickness of these flakes.

The core used as blank is not surprising, common in many assemblages. The proportion of the retouched cores is small and could be regarded as unimportant, the cores being complementary blanks, especially the thick ones. A part of the flake tools and the retouched cores have the same size as some pebble tools indeed. The size is between 20 and $30 \mathrm{~mm}$, as for the flakes.

What is more striking is the connection with a specific core section and particular removals. Their retouch is similar to that on the flakes, on a part of the cutting edge, but they are frequently opposite to a back. Furthermore, some of the last removals on these cores cannot be linked to a debitage and they could be considered as a shaping stage before the retouch, in regard to their location. Thus flake production and shaping would be alike in the toolmaker's mind. Even not exhausted, the cores would become a blank for the retouch.
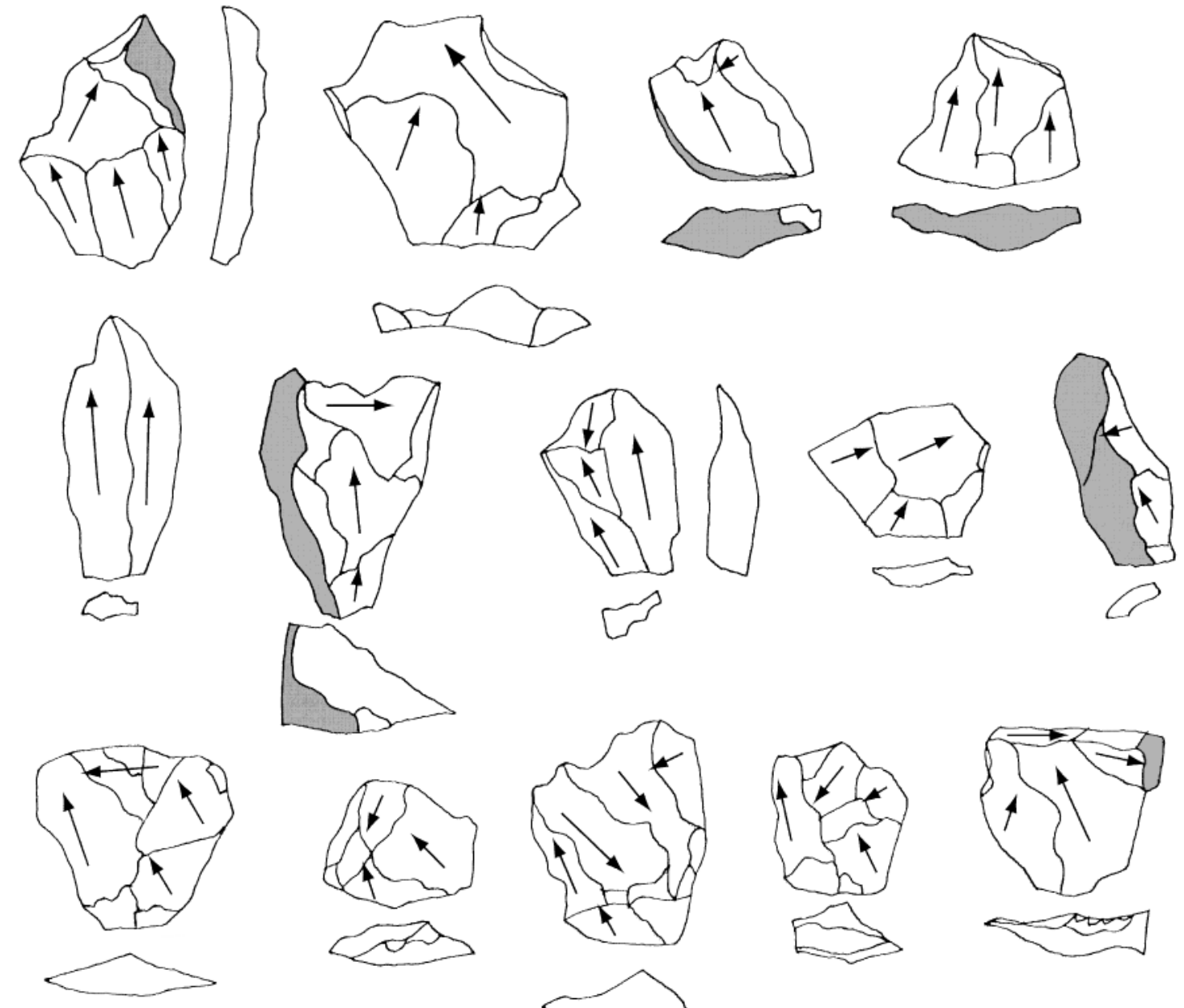

Tata flakes
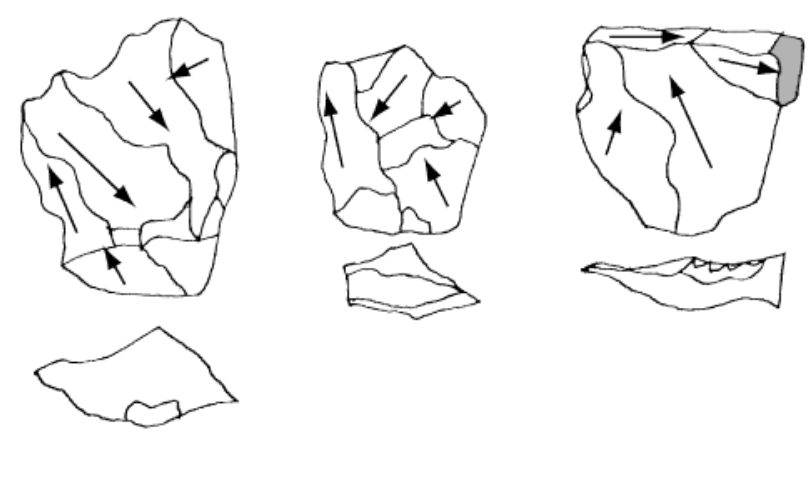

$1 \mathrm{~cm}$

Fig. 6. Tata, flakes: backed flakes and thick flakes

6. kép. Tata, szilánkok 

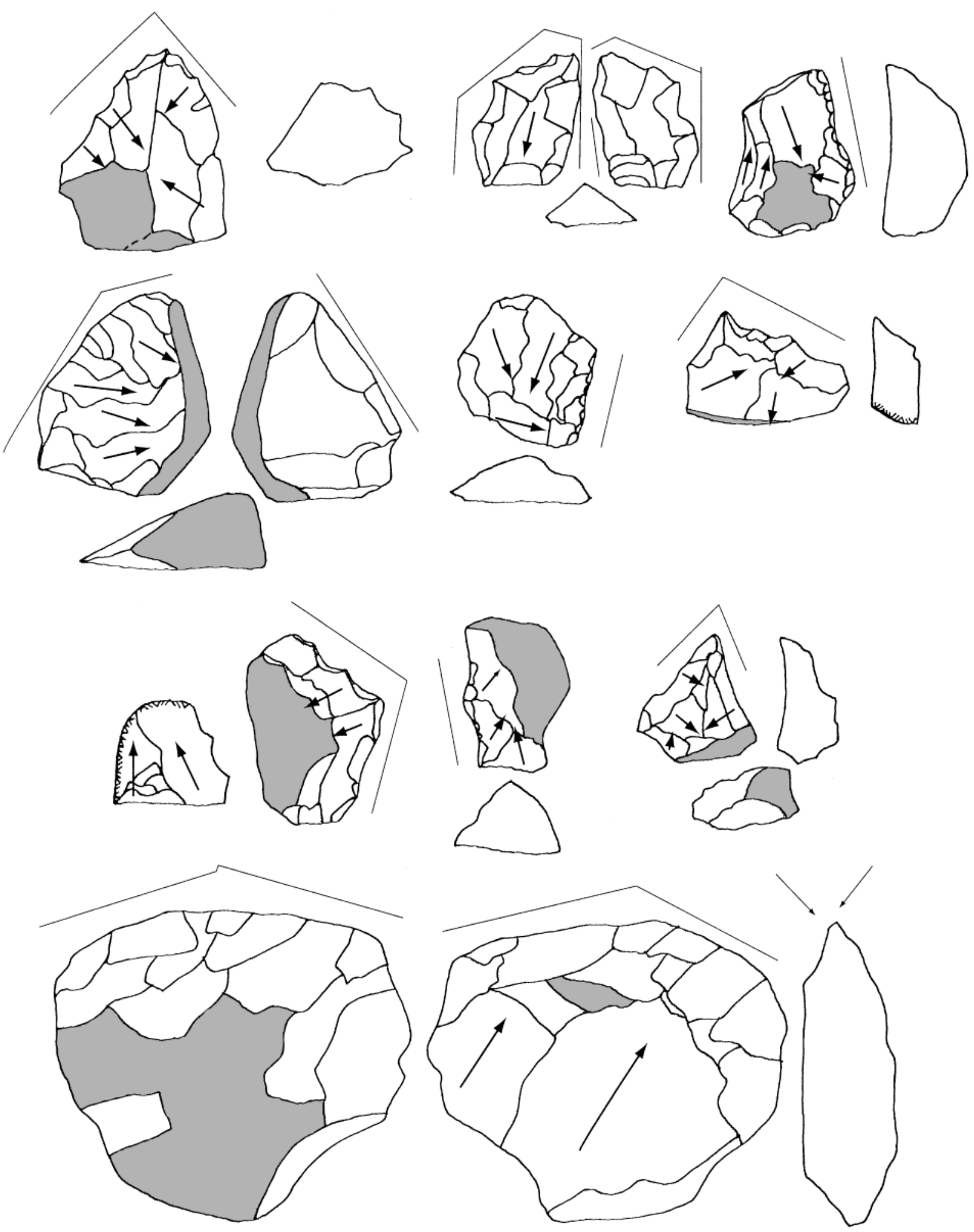

Tata tools

$1 \mathrm{~cm}$

Fig. 7. Tata, tools on flakes: side-scrapers and points

7. kép. Tata, kaparók és hegyek szilánkon 
The cores: evidence of a unique "chaine opératoire"

Two main groups of cores can be technologically distinguished, and the most frequent have two opposite surfaces limited by a cutting edge (Table 5). Most of them measure between 30 and $40 \mathrm{~mm}$, but the general sizes are between $20 \mathrm{~mm}$ and more than $60 \mathrm{~mm}$ (some artefacts) (Fig. 8). The raw materials used are mostly the silicites and radiolarites, the most frequent stones.
- Cores with two opposite surfaces

The spread of the cortical remains and their location is the main clue in distinguishing these cores. These cortical patches, on a pebble or a flake, are more or less invasive on one of the two surfaces. Cores with two faces bearing cortical patches are rare. The original cortex is often preserved on one of the core faces, used as striking platform without preparation, in particular when flat and with a proper angle. When some

Table 4

Feature and size of the flake tools in Tata assemblage

\begin{tabular}{|c|c|c|c|c|c|c|}
\hline $\begin{array}{l}\text { Length } \\
\text { in } \mathrm{mm}\end{array}$ & $10-15$ & $15-20$ & $20-25$ & $25-30$ & $30-40$ & $>40$ \\
\hline Oval flakes & $10.4 \%$ & $2.8 \%$ & $36.2 \%$ & $40.0 \%$ & $5.7 \%$ & $4.7 \%$ \\
\hline Triangular flakes & $11.1 \%$ & $1.9 \%$ & $37.9 \%$ & $38.5 \%$ & $8.5 \%$ & $1.9 \%$ \\
\hline Square flakes & $9.8 \%$ & $1.6 \%$ & $36.0 \%$ & $40.9 \%$ & $11.4 \%$ & \\
\hline Broken flakes & $29.2 \%$ & $41.4 \%$ & $12.2 \%$ & $12.2 \%$ & $2.4 \%$ & $2.4 \%$ \\
\hline Cores & $3.5 \%$ & $3.5 \%$ & $35.7 \%$ & $42.8 \%$ & $14.2 \%$ & \\
\hline Cortical first flakes & $21.4 \%$ & $6.1 \%$ & $19.4 \%$ & $43.6 \%$ & $13.4 \%$ & $2.7 \%$ \\
\hline
\end{tabular}

Sample: 600 artefacts

Table 5

The different types of cores in Tata

\begin{tabular}{|c|c|c|c|}
\hline Type of cores & Frequency & Striking platform or debitage surface & Debitage surface \\
\hline $\begin{array}{l}\text { A: } \\
2 \text { opposite surfaces } \\
1 \text { cortical }\end{array}$ & $41-15 \%$ & $\begin{array}{l}\text { total cortical surface or a few removals } \\
\text { trapezoidal or oval butt of a pebble or } \\
\text { a cortical flake }\end{array}$ & $\begin{array}{l}\text { triangular or trapezoidal section without } \\
\text { cortex } \\
\text { centripetal or crossed removals } \\
\text { (some unipolar or bipolar removals) }\end{array}$ \\
\hline $\begin{array}{l}\text { B: } \\
2 \text { opposite surfaces } \\
\text { large cortical remains }\end{array}$ & $33-7 \%$ & $\begin{array}{l}\text { large cortical patches } \\
\text { butt of a pebble or a flake } \\
\text { use of the morphology of the blank } \\
\text { (some centripetal or crossed removals) }\end{array}$ & $\begin{array}{l}\text { trapezoidal or flat surface } \\
\text { without cortex } \\
\text { centripetal or crossed removals } \\
\text { (some bipolar removals) }\end{array}$ \\
\hline $\begin{array}{l}\text { C: } \\
2 \text { opposite surfaces } \\
\text { limited cortical remains }\end{array}$ & $18-12 \%$ & $\begin{array}{l}\text { pyramidal, trapezoidal sections } \\
\text { centripetal or crossed removals }\end{array}$ & $\begin{array}{l}\text { numerous flat surfaces } \\
\text { centripetal removals }\end{array}$ \\
\hline $\begin{array}{l}\text { D: } \\
2 \text { opposite surfaces } \\
\text { a cortical back }\end{array}$ & $114-32 \%$ & $\begin{array}{l}1 \text { or } 2 \text { cortical backs on a part of the core } \\
\text { periphery (partial edge): part of a pebble } \\
\text { or a flake as a natural striking platform } \\
\text { step removals trapezoidal section }\end{array}$ & $\begin{array}{l}\text { flatter surface } \\
\text { centripetal, crossed and uni-bipolar removals }\end{array}$ \\
\hline $\begin{array}{l}\text { E: } \\
2 \text { opposite surfaces } \\
\text { without cortex }\end{array}$ & $14-5 \%$ & $\begin{array}{l}\text { centripetal or crossed removals } \\
\text { use of the core edges (backed removals) } \\
\text { pyramidal or convex section }\end{array}$ & $\begin{array}{l}\text { centripetal or crossed removals } \\
\text { use of the core edges (backed removals) } \\
\text { pyramidal or convex section } \\
\text { non symmetric core }\end{array}$ \\
\hline $\begin{array}{l}\text { F: } \\
1 \text { debitage surface } \\
\text { pebble slices }\end{array}$ & $14-5 \%$ & $\begin{array}{l}\text { butt of an oval pebble or a cubic pebble } \\
\text { rare small removals }\end{array}$ & $\begin{array}{l}\text { convex or flat surface without cortex or } \\
\text { limited patches } \\
\text { pebble slices (unipolar, bipolar, crossed axis) }\end{array}$ \\
\hline $\begin{array}{l}\text { G: } \\
\text { orthogonal surfaces } \\
\text { on a pebble }\end{array}$ & $49-14 \%$ & \multicolumn{2}{|c|}{$\begin{array}{l}\text { use of the pebble faces (cubic or quadrangular pebbles) } \\
\text { several debitage faces }(2,3 \text { or more) } \\
\text { more or less large cortical patches } \\
\text { cortical striking platform or use of the previous removals } \\
\text { short debitage }\end{array}$} \\
\hline
\end{tabular}


removals exist, small and located in limited areas, they could be a minor preparation. According to the pebble or flake shape, the number and the size of these removals is, consequently, more or less. When the cortex does not exist anymore, the two opposite surfaces can be considered as debitage surfaces (Fig. 9).

Except the extent of cortical remains on one or the two surfaces, the technological study suggests that all the assemblage cores could be different stages in a unique processing system, keeping cortical surfaces when convenient. Some cores suggest they were knapped for long, eliminating the cortex on the two faces. Each surface is used for the debitage, according to the angles.

The removals are, above all, centripetal or crossed. The unipolar or bipolar removals are rare. Furthermore, a large proportion of the removals are deep. The morphology of the flaking surface is, consequently, various (pyramidal, trapezoidal, convex or even flat), and the core section frequently is not symmetric. One surface is often left more flat than the opposite one, especially when there is a large patch of cortex (pyramidal section). The flaked face shape may be sometimes explained by the removal organisation. Backed flakes are frequent during the debitage and this kind of practice leads to a flat core surface and a production of thick backed flakes or pebble slices. The removals never converge to the centre of the core. A large use of flakes as cores also explains the proportion of flat flaked surfaces in spite of a short reduction sequence. Remains of a ventral flake surface are still visible

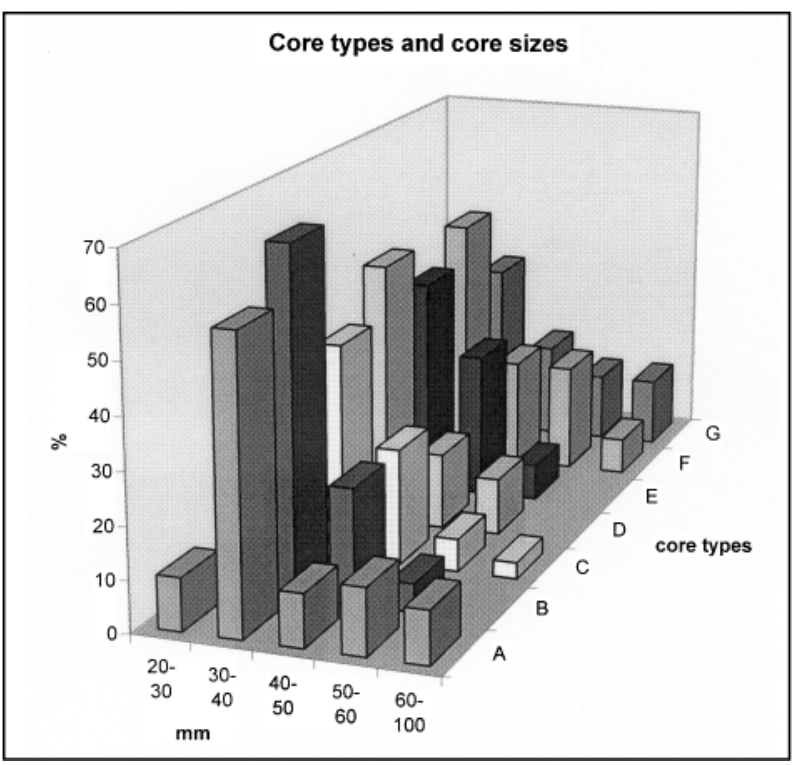

Fig. 8. Tata, core types and sizes

8. kép. Tata, magkő típusok és méretek (thin and short removals). Thus, a high frequency of flat flaked surfaces in an assemblage does not prove that the Levallois method was practiced (Fig. 10).

The last removals are often hinged, especially the small ones. The angle value between the striking platform and the debitage surface or the flat shape of the flaked surface is a conceivable reason to explain such numerous latest attempts which cannot lead to a positive result. On the contrary, in some cases, these hinged removals and other larger ones does not seem to be a last step in the reduction sequence. By their location, these removals rather seem to shape the core for another use than to product a flake and could be related to the core selection for tool. Flaking and shaping would be linked to produce large and thick blanks which are independently available through debitage or shaping. Thus, this could belong to the technological behaviour of the toolmakers.

The cores are mainly not exhausted and the toolmakers tried to pursue their work in creating a third surface in a few cases. Perhaps it was more efficient to collect new pebbles because the core size became too small, or the pebbles were so abundant in the surroundings.

Among the group of cores with two flaking surfaces, some types are not only stages in a more or less developed processing system. They are cores with a cortical back (base of a pebble or a cortical back of a flake) (Fig. 9). This back is kept on the core all along the flaking and no gesture has tried to eliminate it (partial cutting edge on the core). The two debitage surfaces show a similar processing system as on the other cores. However, the debitage is not initiated on the entire periphery, although it covers the whole surface. This back seems to be rarely used as a practical striking platform, undoubtedly because of the wide angle between the back and the surfaces. By their frequency (more than 30\% of the total cores), this kind of cores and flaking could be evidence of a specific behaviour of the toolmakers, indicating perhaps the search for backed artefacts, which are actually numerous in the assemblage.

\section{- Cores with a multidirectional debitage}

Associated with the cores with two opposite surfaces, some cores show a multidirectional reduction on each face of a cubic or quadrangular pebble. There is no preparation and the striking platform is on each face. Two, three or more orthogonal flaking surfaces can be counted on these cores. Less numerous, they can be considered as 


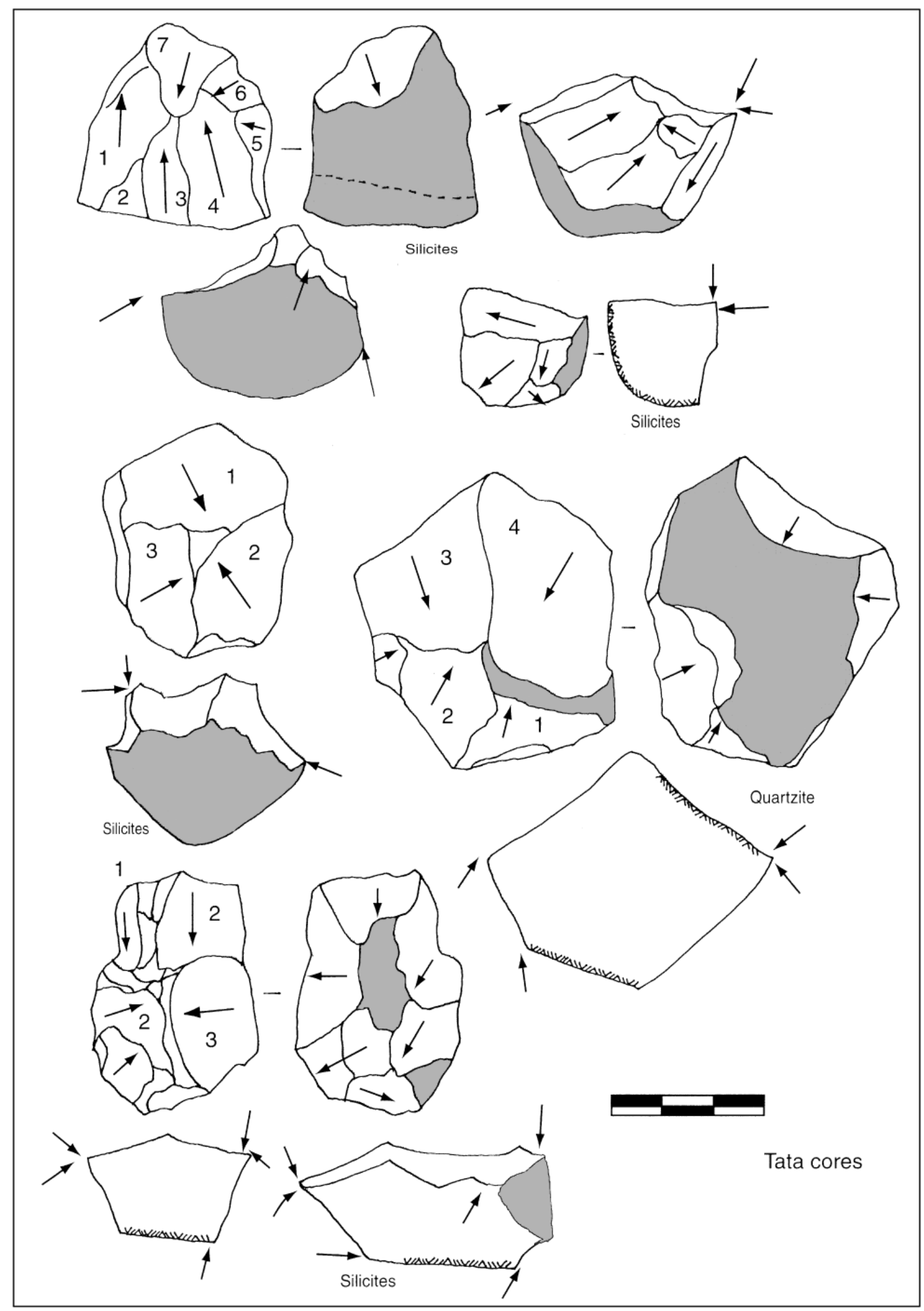

Fig. 9. Tata, cores: numerous two opposite flaking surface, some cores with orthogonal surfaces, frequent crossed removals and cortical back on some cores

9. kép. Tata, magkövek, különböző szilánkleválasztási módok 
secondary and as evidence of an opportunistic method. However, some of these cores could be technological stages in a pebble slice extraction made first on a unique face, second on two, three or more orthogonal faces. Furthermore, a connection between the two main core groups exists. Sometimes, a third flaking face has been worked on a core with two opposite surface, orthogonal to the other ones.

According to the technological analysis and the removal organisation, the processing system used by the toolmakers in Tata belongs to a unique conception materialised by two methods (Fig. 11). It could be linked to the large family of the discoïdal debitage. This method uses the pebble shape and volume and the diversity of the removal locations is due to the variety of the collected pebbles, the quality of each raw material and the types of expected products. The choice of flaking preferentially two opposite flaked surfaces characterises the Tata assemblage and most abandoned cores would be different stages in a unique processing system. In this way, different types of flakes can be produced, thin or thick, short or elongated and any core can be considered as specialised, for example, for the production of laminar blanks. Each kind of blank were produced at different moments, along the processing system which needed numerous pebbles. Most of the cores only produced some flakes. The high number of the pebbles used can be perhaps due to repeated human settlements. However, the small size of the raw material blanks certainly also resulted in a large collecting to meet the requirements.

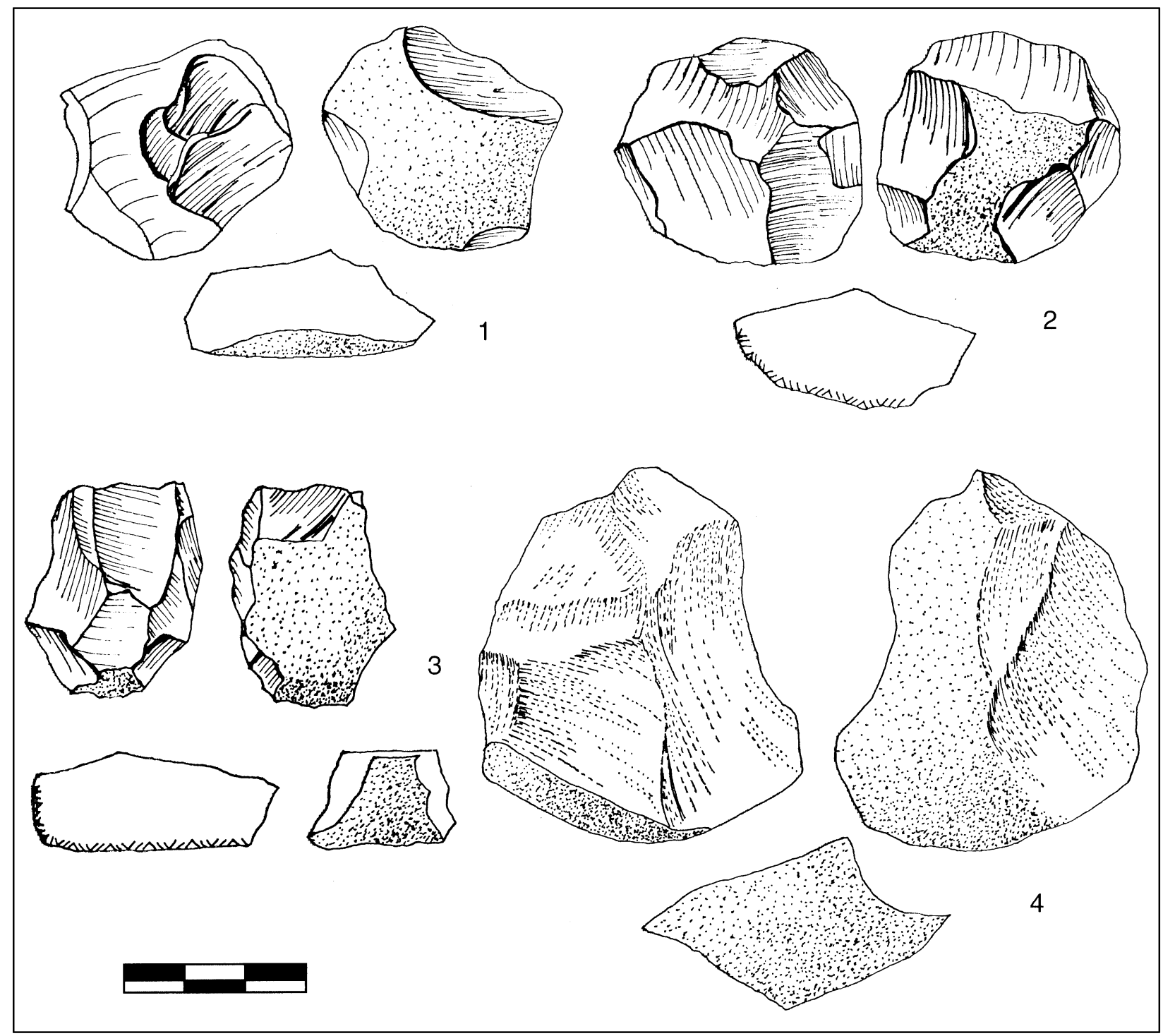

Fig. 10. Tata, cores: 1-3 silicites, 4 quartzite

10. kép. Tata, magkövek: 1-3 kova, 4 kvarcit 


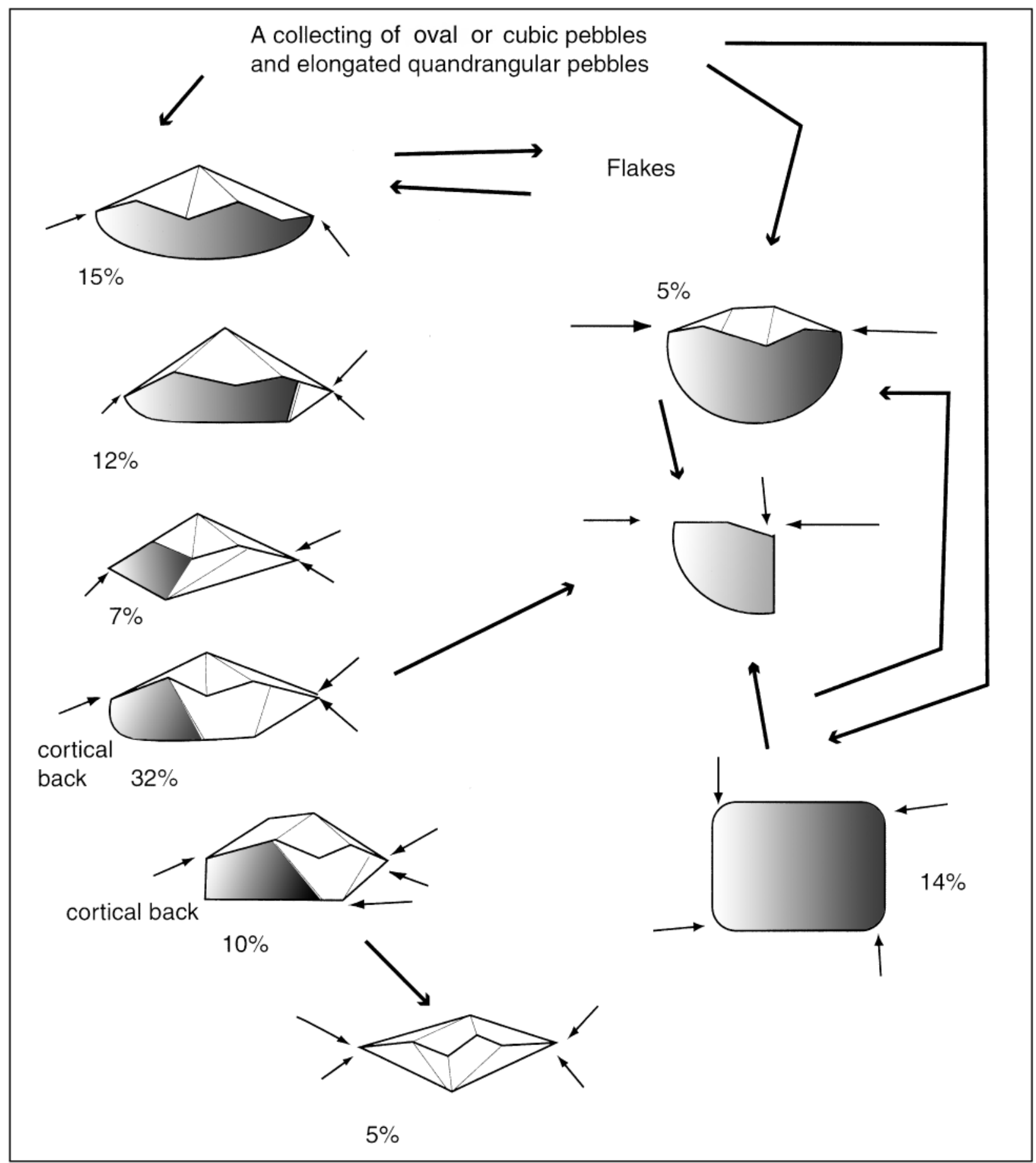

Fig. 11. The Tata processing system: an unique behaviour to various products

11. kép. A kőeszközök előállításának sajátosságai Tatán

The human behaviour in a microlithic assemblage

- The pebble size: "a microlithic world"

The industry of the Tata assemblage is mainly microlithic, this size appearing intentional. The local collecting of very small pebbles from various raw materials characterises first the industry and it was not completely imposed by the environmental settings. Actually, large pebbles were present around the sites, in diverse good quality rocks, and some of them have evidently been collected by humans. This kind of stone collecting is also observed in other similar sites. Analysis of the OIS 5 and 4 microlithic assemblages, as from 
Kůlna level 11 or Předmost II levels 9 and 8 in the Czech Republic, confirms that humans collected most of their pebbles around the site. Rocks from a long distance area are very rare or missing. In Kůlna, few artefacts from a long distance area are in specific rocks such as "porcelanite". They were only brought as finished tools and the kind of retouches could be evidence of a specific treatment of extraordinary stones or of an exchange between human groups. ${ }^{23}$ The pebble size is comparable in these three assemblages, mostly between 20 and $50 \mathrm{~mm}$. Some pebble tools are even on blanks which measure less than $20 \mathrm{~mm}$. The treatment of the larger pebbles is similar to that of the smaller ones. Some of these large pebbles are used as hammers or pebble tools, while other ones have been exploited for the debitage. The debitage surfaces of these large cores always show small scars, as on the smallest cores. Consequently, if the environmental settings favoured the pebble collecting, it did not completely control the lithic production. There was really a specific human behaviour, preferentially oriented towards small blocks, from diversified rocks, and to a microlithic flaking. A large quantity of collected pebbles occurs in each site. This number can be explained by the accumulation of numerous settlements. It could also be related to the pebble size and the reduction sequence requiring a large quantity of pebbles to produce the flakes.

- The reduction sequence in Tata in Hungary, Külna and Predmost II in the Czech Republic

The reduction sequences used in Tata show numerous common points with Kůlna level 11 and Předmost II. ${ }^{24}$ Most cores belong to a same processing system, based on two opposite flaking surfaces. This system can also be described as a justified treatment of the volume of small pebbles, their cortical faces and their morphology. Quadrangular pebbles are the most common, and a possible choice by the toolmakers. It is easier to begin a flaking from flat surfaces than convex ones. The round and oval pebbles are in great majority reserved first for the pebble tools. This specific use of the pebble shape is also observed on some cubic cores with a few scars on each cortical faces. The kind of flaking can be regarded as parallel to the large discoidal family, really different of what is described in other assemblages considered as microlithic such as Taubach. ${ }^{25}$ Recent analysis in Pontinian assemblages in Italy, dating to the OIS 4, also shows various flaking methods, different from Central Europe (double percussion method, pebble slice method, two opposite surface cores). ${ }^{26} \mathrm{~A}$ variety on the same scale is also observed among Pontinian sites as among Tata, Kůlna and Předmost II. Thus, through the processing system studies, technological traditions appear among microlithic assemblages, not due to the raw materials.

\section{- A genetic link with older sites: Vértesszőlős in Hungary}

A large "microlithic" tradition or trend could be inferred from the reduction sequence, similar in three sites dating from the same period and in various contexts (open-air site for Tata and Předmost II, cave for Kůlna). This tradition could also exist over time, the same flaking method being found in Vértesszőlős, in Hungary, dating from the OIS 9. According to our analysis, numerous cores show a debitage method based on two opposite surfaces with the same rules as in Tata (Fig. 12). The management of these cores is, however, shorter, stopping after a few cortical removals. They are associated to a large exploitation of small pebbles by breakage (large quantity of chucks, pebble slices, pebble quarters and first cortical thick flakes). Whatever that may be, a genetic link cannot be discarded among old sites such as Vértesszőlős or even Bilzingsleben, and more recent ones in the same geographical area. ${ }^{27}$ Microlithic trends would have to be considered as a human choice, punctually occurring again over time.

The pebble size does not explain this kind of technological behaviour. We can see the same type of reduction in Érd, another Middle Palaeolithic site in Hungary, where large pebbles have been collected. ${ }^{28}$ It is also the case in the Micoquian levels in Kưlna in the upper part of the sequence, above the microlithic assemblage level 11 and dating to the OIS 4 , under cold conditions. ${ }^{29}$

\footnotetext{
23 VAlOCH 1987, 1996b; MONCEL-NerUda 2000.

24 Moncel 1997-1998; Moncel-Svoboda 1998, MoncelNERUDA 2001.
}

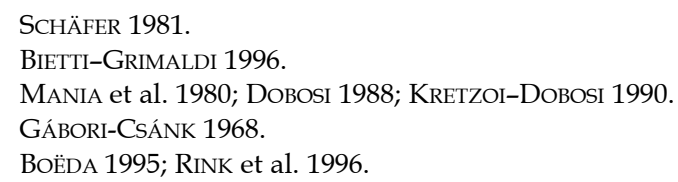



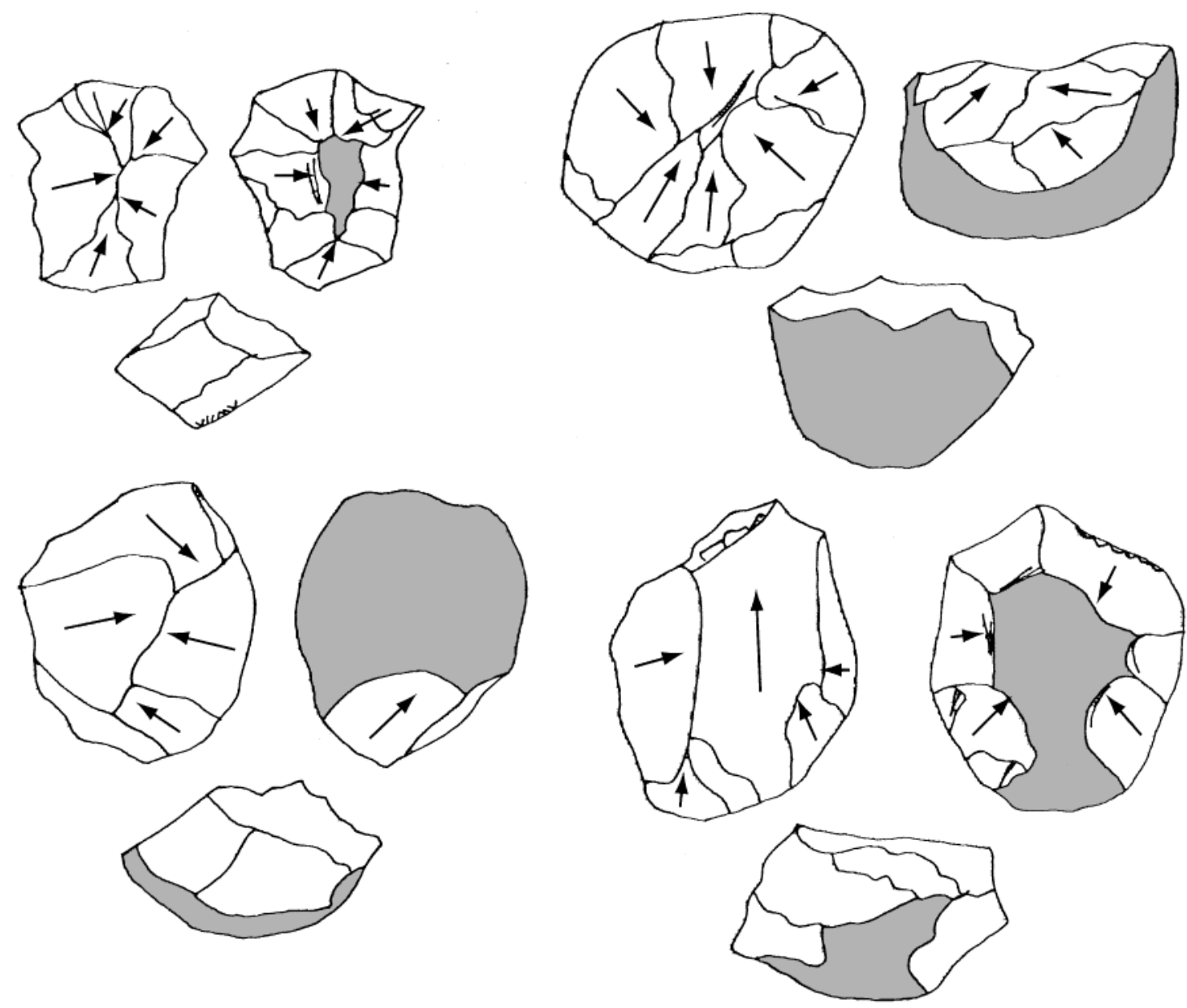

\section{Vértesszölös cores}

Fig. 12. Vértesszőlős cores with two opposite flaking surface

12. kép. Alsópaleolit magkövek Vértesszőlősről

- Another conception of the tools?

If traditions really persist over time within a microlithic world, without environmental explanations (for example, a lack of large pebbles), Neanderthals were able to use very small blanks coming from diverse methods. Facing of such data, the manner in which they used these small flakes has to be considered, perhaps from a different point of view. Anthropological analysis of the Neanderthal hand provided evidence that it was more powerful that of Homo sapiens. ${ }^{30}$ These artefacts could, thus, simply be held alone at hand. Nevertheless, the morphology and the location of the retouch for most flakes can lead to other hypotheses. In Tata, numerous flakes are backed, triangular or elongated. The tools are rather rare, either side-scrapers or points. The retouch is ordinary and, above all, on one face, on the cutting edge opposed to the back or on the two converging edges. The bladelets are less retouched. The points are often with a partial bifacial retouch, especially located on the base. Various studies on points show that these ones could be used by hand, as a butchery knife, or fixed in a wooden handle, as a projectile. ${ }^{31}$ The retouches are not always the utilised part of the artefact and the flat retouch can be a "shaping" retouch to fix more easily the stone artefact. 
Consequently, we can imagine that the frequent retouched backed flakes, the unifacial, bifacial or partial points, or the rough bladelets and flakes could be fixed separately or together in a wooden handle, as studies on Mesolithic or Neolithic assemblages suggest. Remains of bitumen on points have been discovered in the site of Ummel-Tell (Syria), suggesting a usual preparation of hafted points. ${ }^{32}$ The common characteristics of the microlithic assemblages with other ones with large flakes could indicate a similar range of use of the artefacts. However, the frequency and the size of the small artefacts could also indicate another relation to the tool kit, requiring flakes in large number, side-scrapers and points in various quantity according to either the activities or the habits.

The many clues for wood use by Neanderthal groups can also be a potential direction of research. These small artefacts could be yet tools to prepare wooden tools, especially when the environmental context is composed of large forest patches. The results from the microwear analysis in Grotta Breuil, yielding a microlithic assemblage related to the Pontinian (Italy), indicate a large number of cutting edges having worked on wood. ${ }^{33}$ Sharp cutting edges seem to be very efficient to work wood, as well as denticulates, as attested by various ethnographic examples. ${ }^{34}$ Sites which yielded organic tools often show an association between wooden artefacts and various stone tools such as partial or total points with uni- or bifacial retouches or side-scrapers on thick flakes. ${ }^{35}$ This association can be seen as functional. In other cases, organic implements are associated with small stone tools (points or side-scrapers on thick and cortical flakes) and large pebble tools. ${ }^{36}$ The production on the Tata site provided very small flakes (10-30 $\mathrm{mm}$ long), some micro-choppers (10 to $30-40$ $\mathrm{mm}$ long) and only some large pebbles. The wooden tools could be complementary to smaller tools in stone for the activities. Moreover, the great quantity of compressors in assemblages with numerous small artefacts (for example, Bilzingsleben, Vértesszőlős, Kůlna or Tata) indicate a large variety of raw materials used by these humans, and then the likely necessity of using of hard surfaces perhaps to prepare small stone artefact edges.

\section{- Specialised settlements?}

While in the eastern part of Europe, the microlithic assemblages are linked with various kinds of sites and fauna in relation to the environmental context, in Central Europe, they are more often associated with hot water springs. Some lucky discoveries could explain it, such as the excellent preservation of remains in the travertine deposits. However, in spite of the current knowledge about sites in this geographical area, this specific location could notice a type of settlement for human groups with a microlithic tradition. It may have provided evidence of original human settlements in favourable areas for animals and vegetation. ${ }^{37}$ Mobile human groups could find easy prey regardless to the environment. The scale of this mobility is impossible to estimate, even if assemblages include some long distance area stones. Researchers suggest that the discovery of these rocks indicates the territory size. Nevertheless, exchanges among human groups or mobile isolated humans could as well explain the movement of such strange objects. ${ }^{38}$ From more than $100 \mathrm{~km}$, the long distance area rocks in Kůlna are totally different from the whole lithic assemblage by their shaping, which, in contrary, looks like those of the Tata artefacts. Relations among groups inside Central Europe basins, through geographical gates, are not still demonstrated but artefact exchanges or collecting of extraordinary objects in an extend territory have to be discussed to survey the microlithic assemblages in a spatial point of view. The Tata bifacial points would be, in this case, evidence of traditions and not just functional needs.

While Kůlna level 11 only yields some elephant remains, the Tata assemblage yields young elephant remains as a main component. ${ }^{39}$ Unfortunately, these elephant remains are too few to implement a discussion on the evidence of hunting or scavenging. They indicate at least one or several summer settlements. Western site studies suggest that humans do hunted large herbivores such as the rhinoceros or the elephant, especially on young animals. ${ }^{40}$ Further-

\footnotetext{
32 BOËDA et al. 1996.

33 LEMORINI 2000.

34 LEROI-GOURHAN 1973.

35 For example, Schöningen or Lehringen, Germany, THIEMEVeIL 1985; THIEME 1999.

36 For example, Bilzingsleben in Germany, MANIA 1988b.
}

\footnotetext{
37 MONCEL 2001b.

38 MONCEL-NERUdA 2000; MONCEL 2001c.

39 VALOCH 1988; ZELINOVA 1998.

40 Auguste et al. 1998.
} 
more, the high density of artefacts and bones seems to indicate that men could have regularly occupied the water spring banks, possibly for hunting great herbivores on a large scale. For example, in Taubach (Germany), the high frequency of young rhinoceros of 1-1.5 year old (Stephanorhinus kirchbergensis) in the bone assemblage attests an easy prey hunting. ${ }^{41}$ On the 62 juvenile animal bones, numerous cut marks have been observed, especially on tibias. The rhinoceros bones are associated with Ursus arctos bones which also bear cut marks. Bison priscus, Castor fiber and Cerous elaphus are well-represented but with few bone fragments with cut marks. The rhinoceros mortality curve does not show a catastrophic profile, and according to B. Bratlund, this is evidence for an active hunting during repeated settlements. It would be the same case in Gánovce with both Elephas antiquus and Dicerhorinus mercki. ${ }^{42}$

If it is difficult to admit that the small tools have been used for hunting, except the points, it is conceivable that they could have been, at least, used for the animal processing. Aerodynamic studies on stone points from Middle Palaeolithic assemblages suggest, in the state of knowledge, a high penetration at short distance because of their large base. ${ }^{43}$ A close distance necessary for hunting implies a particular kind of subsistence behaviour. If the small points have been used as projectiles, it could perhaps explain the choice of water springs to stay, in order to pick up dead or injured animals or to hunt easy preys.

According to the site, the blank categories vary while the processing system remains the same. In Tata, triangular flakes and elongated flakes (laminar flakes and bladelets) are more frequent among the assemblage than in Kưlna or Předmost II. Bifacial points also characterise the tool kit. It could be attractive to see within these tool types a clue for a larger range of activities and perhaps a more developed hunting in Tata. The bifacial points or the flat retouch on the blank butt would have been more efficient to haft them. Nevertheless, the idea of a different tradition can no longer be discarded, as the rare bifacial tools in Kůlna suggest. Furthemore, technological studies in the recent years have focused on the danger to closely associate a flaking method, such as the discoidal method, with a specific activity such as a large hunting and

\footnotetext{
1 BRATLUND 1999

42 LOZEK 1954.

43 ELLIS 1997; KNECHT 1997.

44 Tuffreau 1993; Moncel et al. 1998; Moncel 2001a.
}

butchery processing. ${ }^{44}$ Each flaking method, especially the laminar processing method, is able to produce efficient blanks to treat animal corpses. The toolmakers actually selected among their technical abilities the best processing systems, or several ones, to meet the needs of the human group during a settlement. In Tata, the debitage method used, similar to those in Kůlna, Předmost II and even Vértesszőlős, certainly attests a large range technological behaviour over space and time, whatever the climatic changes.

At least, some assemblages show that large herbivores with cut marks and evidence of hunting are associated in Central Europe during the OIS 5 and 4 with humans, using in particular microlithic assemblages. The frequent occurrence of these human occupations in water spring locations is most likely evidence of deliberate behaviour of some European Neanderthal groups who knew the extraordinary richness of life and natural resources around the springs. These groups used small pebbles in various rocks and made small tools. Activities could be varied and butchery activities cannot only be related to these settlements in regard to the tool type, the blank variety and, especially, the number of bones broken for the marrow. It is another technological world, intentionally microlithic, with certainly another conception of the tool kit.

\section{Summary}

The site of Tata, located in Hungary, has yielded two famous "artistic objects" dated to the isotopic stage 5. However, this site is also famous for its very strange lithic assemblage, most of which is smaller than $30 \mathrm{~mm}$. Other OIS 5 sites in Central Europe have yielded microlithic assemblages which are not always related to specific raw material conditions. Few human remains provide evidence that Neanderthals were the authors of these assemblages. The settlements are often linked to water springs and the fauna assemblages are composed of one or two great herbivores (deers, horses, rhinoceros and elephants). The analysis of fauna remains suggests that some of these animals could be hunted. The herbivore bones are associated with very small flakes, showing the diversity of the human technical behaviours adapted to all kinds of subsis-

\footnotetext{
44 Tuffreau 1993; Moncel et al. 1998; Moncel 2001a.
} 
tence patterns. The technological analysis of the assemblages, in particular of the cores, provides new patterns about the technological choice for flaking, which seems to belong to a specific tradition. This hypothesis is indirectly confirmed by comparative studies of several microlithic industries from the OIS 11 to 4-3, such as Vértesszőlős in Hungary, or Kůlna and Předmost II in the Czech Republic. The microlithic assemblages are associated with various environments and could be one of the human responses to organise the stone tool production. It could also be evidence of another technological conception of the tools.

\section{Acknowledgements}

This work was supported by the C.N.R.S. in France through a research project. Many thanks to Dr. V. Dobosi from the Hungarian National Museum in Budapest, Hungary, for her help, discussion and interest to this study. Many thanks also to Professor K. Valoch, from the Anthropos Institute in Brno, in the Czech Republic, and Professor J. Svoboda, from the Academy of Sciences in the Czech Republic, for all their help and their great knowledge on Central Europe.

\section{BIBLIOGRAPHY}

Auguste, P.-Moncel, M.-H.-Patou-Mathis, M.

1998 Chasse ou "charognage" acquisition et traitement des Rhinocéros au Paléolithique moyen en Europe Occidentale. In: Economie préhistorique: les comportements de subsistance au Paléolithique en Europe. Eds BRugal, J.-P.-Meignen, L.-PATOU-Mathis, M., 133-153.

BÁNESZ, L.

1991 Die Entwicklung der Travertine in den Nordkarpaten im Lichte archäologischer Funde. Quartär 41-41, $45-62$.

BEHM-BLANKE, G

1960 Altsteinzeitliche Rastplätze im Travertingebiet von Taubach, Weimar, Ehringsdorf. Alt-Thüringen 4, Weimar.

BEYRIES, S.-WALTER, P.

1996 Racloirs et colorants à Combe-Grenal. Le problème de la retouche Quina. Quaternaria nova VI, 167-187.

BIETTI, A.-GRIMALDI, S.

1996 Small flint pebbles and Mousterian reduction chains: the case of southern Latium (Italy). Quaternaria nova VI, 237-261.

BOËDA, E.

1995 Caractéristiques techniques des chaînes opératoires lithiques des niveaux micoquiens de Kůlna (Tchécoslovaquie). Paléo, Actes du Colloque de Miskolc 57-73.

BOËDA, E.-CONNAN, J.-DessorT, D.-MuHESEN, S.-MERCIER, N.-VAlladAs, H.-Tisnerat, N.

1996 Bitumen as hafting material on Middle Paleolithic artifacts. Nature 380, 336-338.

BORDES, F

1984 Leçons sur le Paléolithique. Bordeaux.

BRATLUND, B.

1999 Anthropogenic factors in the Thanatocoenose of the last Interglacial Travertines at Taubach (Germany). In: The Role of Early Humans in the accumulation of European Lower and Middle Palaeolithic bone assemblages. Eds GAUDZINSKI, S.-TuRner, E. Monographien des Römisch-Germanischen Zentralmuseums 42, 255-263.

BRUNNACKER, K.-JAGER, K. D.-GEND, H.-PREUSS, J.-GRÜN, R.

1983 Radiometrische Untersuchungen zur Datierung mitteleuropäischen Travertinvorkommen. EAZ 24, 217-266.

BURDUKIEWICZ, J.

1993 A Lower Palaeolithic settlement at Trzebnica (South-West Poland). XIIème UISPP 1991 Bratislawa 2, 26-32.

BuRduKIEWICZ, J.-MANiA, D.-Kocon, A.-WebER, T.

1979 Die Silexartefakte von Bilzingsleben. Zu ihrer morphologischen Analyse, EAZ 20, 682-703.

BURDUKIEWICZ, J. M.-SNIESZKO, Z.-WINNICKI, J.

1994 A Lower Palaeolithic settlement at Trzebnica (SW Poland), EAZ 3, 27-40.

Carbonell, E.-Castro-Curel, Z.

1992 Palaeolithic Wooden Artefacts from the Abric Romani (Capellades, Barcelona, Spain). Journal of Archaeological Science 19, 707-719.

Derevianko, A. P.-Petrin, V .T.-Taimagambetov, Z. K.-Otte, M.

1998 Early Palaeolithic assemblages in travertine, Southern Kazakhstan (a variant of an adaptation model). Anthropologie XXXVI/1-2, 137-164. 
Dobosi, V. T.

1983a Die Knochenartefakte von Vértesszőlős. EAZ 24, 349-361.

DoвOSI, V. T. 1983b Data to the evaluation of the Middle Palaeolithic industry of Tata. FolArch XXXIV, 7-32.

DoBOsI, V. T. 1988 Le site paléolithique inférieur de Vértesszőlős, Hongrie. L'Anthropologie 92/4, 1041-1050.

Doвosi, V. T.

2000 Middle Palaeolithic Phenomena in Hungary. In: Toward Modern Humans. The Yabrudian and the Micoquian (400-50 k-years ago), Proceedings of Congress at the University of Haifa, Eds RonEN, A.-WEINSTEIN-EVRON, M., Oxford: BAR, series 850, 51-61.

ELLIS, C. J.

1997 Factors influencing the use of stone projectile tips: an ethnographic perspective. In: Projectile technology. Ed. KNECHT, H., New York, 37-78.

GÁBORI, M. 1976 Les civilisations du Paléolithique moyen entre les Alpes et l'Oural. Budapest.

GÁBORI, M.-CSÁNK, V.

1968 La station du Paléolithique moyen d’Érd (Hongrie). Budapest.

KAMINSKA, L.-KovANDA, J.-LOZEK, V. SMOLIKOVA, L.

1993 Die Travertinfundstelle Hôrka-Ondrej bei Poprad, Slowakei. Quartär 43-44, 95-112.

KNECHT, H.

1997 Projectile points of bone, antler and stone: experimental explorations of manufacture and use. In: Projectile Technology. Ed. KNECHT, H. New York. 191-212.

KOLLER, J.-BAUMER, U.-MANIA, D.

2001 High-tech in the Middle Palaeolithic: Neanderthal-manufactured pitch identified. European Journal of Archaeology 4-3, 385-398.

KRETZOI, M.-DobOSI, V.

1990 Vértesszőlols. Man, site and culture. Budapest.

KUHN, S. L.

1995 Mousterian Lithic Technology. An Ecological Perspective. Princeton.

LEMORINI, C.

2000 Reconnaître des tactiques d'exploitation du milieu au Paléolithique moyen. La contribution de l'analyse fonctionnelle. Etude fonctionnelle des industries lithiques de Grotta Breuil (Latium, Italie) et de La Combette (Bonnieux, Vaucluse, France). BAR International Series 858, Oxford.

LEROI-GOURHAN, A.

1973 Milieu et techniques. Paris.

LiOUBINE, V. P.

1998 La grotte moustérienne de Barakaevskaïa (Caucase du nord). L'Anthropologie 102-1, 67-91.

LOZEK, V.

1954 Die Weichtiere der Pleistozänen Travertine in Gánovce. Anthropozoikum IV, 104-105.

MANIA, D.

1988 Le Paléolithique ancien et moyen de la région de la Saale et de l'Elbe, Allemagne de l'Est.

L'Anthropologie 92-4, 1051-1092.

MANIA, U.

1995 The utilisation of large mammal bones in Bilzingsleben: a special variant of Middle Pleistocene man's relationship to his environment. In: Man and Environment in the Palaeolithic. Ed. UriCH, H. Études de Recherches Archéoligiques de l'Université de Liège. 239-246.

MANIA, U.

1998 A special aspect of the Cultural evolution, the tools from organic material of the Middle Pleistocene Homo erectus. In: The first Europeans recent discoveries and current debate. Eds CARBONELL, E. et al. Burgos. 151-169.

MANiA, D.-TOEPFER, V.-VLCEK, E.

1980 Bilzingsleben I. Home erectus, seine Kultur und Umwelt. Veröffentlichungen Landesmuseum 32. Berlin.

Merder, O.-Khalail, H.-Rabinovich, R.-Gvirtzman, G.-Wieder, M.-Porat Ron, H.-Bankirer, R.-Saragusti, I.

1998 The Lower Palaeolithic site of Revadim Quarry, preliminary finds. Journal of the Israël Prehistoric Society $28,21-55$.

MONCEL, M.-H.

1997-1998 The eemian lithic assemblages from Předmost II. Technical behaviours from a Middle Palaeolithic microlithic industry. $P V$ 40, 13-34.

MONCEL, M.-H.

1998 Le Paléolithique moyen dans la moyenne vallée du Rhône en France: la question de la variabilité des assemblages lithiques des stades isotopiques 9 à 3. Anthropologie XXXVI/3, 181-199. 
MONCEL, M.-H.

2001a Middle Palaeolithic Assemblages with blades in south-east France. The question of the technical variability during Middle Palaeolithic and its meaning. Archaeology, Ethnology and Anthropology of Eurasia, 2-6, 37-47.

MONCEL, M.-H.

2001b Microlithic Middle Palaeolithic assemblages in Central Europe and elephant remains. Proceedings of the MONCEL, M.-H.

first International Congress, The World of Elephants, Roma, Universista "La Sapienza", 2001, 314-318.

2001c The Raw Material Collecting in the European Middle Palaeolithic. Are there stone exchanges between Neanderthal groups? In: Living space exploitation. Ed. SMYNTYNÁ, O. British Archaeological Reports, Oxford.

MONCEL, M.-H.-SVOBODA, J. S.

1998 L'industrie lithique des niveaux éemiens de Předmost II (Brno, République Tchèque). Fouilles de 1989-1992. Etude des méthodes d'exploitation, des objectifs du débitage et de l'outillage d'un assemblage microlithique du Paléolithique moyen. Préhistoire Européenne 12, 11-48.

MONCEL, M.-H.-NERUdA, P.

2000 The Kůlna level 11: Some Observation on the debitage rules and aims. The originality of a Middle Palaeolithic microlithic assemblage (Kůlna cave, Czech Republic). Anthropologie XXXVIII/2, 219-247.

Moncel, M.-H.-Patou-Mathis, M.-Otte, M.

1998 Halte de chasse au chamois au Paléolithique moyen: la couche 5 de la grotte Scaldina (Scalyn, Namur, Belgique). In: Colloque d'Antibes, Economie préhistorique: les comportements de subsistance au Paléolithique. Eds Brugal, J.-P.-Meignen, L.-PATOU-Mathis, M. 291-309.

OAKLEY, K.-ANDREWS, S.-KeELEY, L.-CLARK, J. D.

1977 A reappraisal of the Clacton spearpoint. Proceedings of the Prehistoric Society 43, 13-30.

PATOU-Mathis, M.

1999 Comportements de subsistance au paléolithique moyen en Europe septentrionale, centrale et orientale. PhD Dissertation, University Paris I.

PLISSON, H.-BEYRIES, S.

1998 Pointes ou outils triangulaires? Données fonctionnelles dans le Moustérien levantin. Paléorient, 24/1, $5-24$.

PROZEK, F

1958 Die archäologische Funde in der Travertinekuppe Hradok. Zusammenfassender Bericht über den Fundort Ganovce und die Reste des Neandertales in der Zips (CSR). Praha.

RADMILLI, A.-BOschian, G.

1996 Gli scavi a Castel di Guido. Firenze.

RANOV, V. A.

2001 The small tools in Lower Palaeolithic industries of the loessic Palaeolithic (Tadjikistan), Pre-prints, XIV UISPP, Liège, 4, 94-95.

RinK, W. J.-SchWARCZ, H.-VALOCH, K.-SeitL, L.-STRINGER, C. B.

1996 Dating of Micoquian Industry and Neanderthal Remains at Kůlna Cave, Czech Republic. JAS 23, 889-901.

Ronen, A.-Burdukiewicz, J.-M.-LAuKhin, S. A.-Winter, Y.-Tsaskin, A.-DAYAn, T.-KulikOV, O. A.-VyachesLAV, K. V.SEMENOV, V. V.

1998 The Lower Palaeolithic site Bizat Ruhama in the northern Negev, Israël. AKorr 28, 163-173.

SCHÄFER, D.

1981 Taubach. Zur Merkmalanalyse von Feuersteinartefakten der mittelpaläolithischen Travertinfundstelle sowie zu ihrem Verhältnis zu Technologie anderer alt- und mittelpaläolithischer Fundplätze. EAZ 22, 369-396.

SCHWARCZ, H. P.-SKOFLEK, I.

1982 New dates for the Tata (Hungary) archaeological site. Nature 295, 590-591.

SHEA, J.

1998 Levantine Mousterian land use and lithic variability, XIII UISPP Congress, Forli, Italy, 1996, abstracts vol. 1, 299-304.

STAPANCHUK, V. N.

1994 The eastern Taubachian: preliminary remarks. AR 46-4, 533-540.

SvOBODA, J.

1994 Das letzte Interglacial von Předmost. Ausgrabungen 1992. EAZ 35, 75-80.

THIEME, $\mathrm{H}$.

1997 Lower Palaeolithic hunting spears from Schöningen, Germany. Nature 358, 807-810.

THIEME, $\mathrm{H}$.

1998 The oldest spears in the world: Lower Palaeolithic hunting weapons from Schöningen, Germany. In: The first Europeans: recent discoveries and current debate. Eds CARBONELL, E. et al. Burgos. 169-195. 
THIEME, $\mathrm{H}$.

1999 Altpaläolithische Holzgeräte aus Schöningen, Lkr. Helmstedt, Germania 77/2, 451-487.

ThIEME, H.-VeIL, S.

1985 Neue Untersuchungen zum eemzeitlichen Elefanten-Jagdplatz Lehringen, Lkr Verden. Die Kunde 36, 11-58.

TufFreau, A.

1993 Riencourt-les-Bapaume (pas-de-Calais): un gisement du Paléolithique moyen. Centre National de la recherche Scientifique DAF 37.

VALOCH, K.

1967 Le Paléolithique moyen en Tchécoslovaquie. L'Anthropologie 71-1-2, 135-143.

VALOCH, K. 1977

VALOCH, K.

1984 Le Taubachien, sa géochronologie, paléoécologie et paléonthologie, L'Anthropologie 88-2, 193-208.

VALOCH, K.

1987 Raw Materials used in the Moravian Middle and Upper Palaeolithic, Inrternational Conference on Prehistoric flint mining and lithic raw material identification in the Carpathian Basin. Budapest-Sümeg, 263-268.

VALOCH, K.

1988a Le Taubachien et le Micoquien de la grotte Kůlna en Moravie. In: L’Homme de Néanderthal. Ed. OTTE, M. Liège 205-217.

VALOCH, K.

1988b Die Erforschung der Kůlna-Höhle 1961-1976. Anthropos Muzeum, Band 14. Brno.

VALOCH, K.

1995 La variabilité typologique du Paléolithique moyen de la grotte Kůlna en Moravie, Paléo, Actes du Colloque de Miskolc. 73-79.

VALOCH, K.

1996a Le Paléolithique en Tchéquie et en Slovaquie, série “Préhistoire d’Europe”, Ed. MiLlion, J. Grenoble.

VALOCH, K.

1996b Anfänge ästethischer Empfindungen im Paläolithikum Mährens und Böhmens, In: Paleolithic in the Middle Danube Region. Ed. SvobODA, J. Brno. 273-279.

VÉRTES, L.

1964 Tata. Eine mittelpaläolithische Travertin-Siedlung in Ungarn. Nova, XLIII. Budapest.

VILLEMEUR, I.

1994 La main des Néandertaliens. Comparaison avec la main des Hommes de type moderne. Morphologie et mécanique. Paris.

WAGNER, E.

1982 Altpaläolithische Funde aus dem mittelpleistozänen Travertin von Stuttgart-Bad Cannstatt. Archäologische Ausgrabungen in Baden Württemberg 1981, 13-17.

WíSNIEWSKI, A.

2001 New Data on the Middle Palaeolithic in the Silesian Lowland. Excavations in the site in Hallera Street

ZELINKOVA, M. in Wroclaw in 2000. Slaskie Sprawozdania Archeologiczne 43, 9-24.

1998 Osteological material from the inside parts of the Kůlna Cave. Acta Mus. Moraviae, Sci. geol. LXXXIII, 147-157.

\title{
A TATAI KÖZÉPSÓPALEOLIT LELÓHELY MIKROLITIKUS KÖIPARÁNAK TECHNOLÓGIÁJÁRÓL
}

\author{
MARIE-HÉLÈNE MONCEL
}

Az Óvilágot 350-300 ezer évtől kezdődően benépesítő népcsoportok fejlett eszközmegmunkáló/szilánkoló technológiájának tanulmányozása időn (jégkori ciklusokon) és téren (egész Közép-Európában) át érvényesülő nagy technológiai hagyományok továbbéléséről tanúskodik.

Egy-egy lelőhely jellegét, karakterét a kőeszközkészlet által hordozott információk, szoros kölcsönhatásban a lelőhelyre vonatkozó minden más adattal, határozhatják meg. A dolgozat a Közép-Európában az utolsó 40 évben ismertté vált mikrolitikus középsőpaleolit iparok, elsősorban Tata technológiai jellemzőit vizsgálja. Kronológiai helyzetük zömmel 5-4 oxigén izotóp fázis, hagyományos terminológiával Eem interglaciális és Würm bevezető szakasza. A számos kultúramegnevezés közül talán a Taubachian a legelterjedtebb, bár nem a legszerencsésebb: a névadó lelőhely nem mondható tipikusnak. 
A tatai kőipar feldolgozásának legfontosabb szempontja az eszközkészítés folyamatában alkalmazott eljárások, technológiai fogások megértése. $A$ "chaîne opératiore"-ral sokkal inkább jellemezhetô egy eszközmegmunkáló hagyomány, mint a tipológiával.

A vizsgálat több mint 20000 tárgyra terjedt ki (ezek túlnyomó többsége szilánk). Ha funkcionálisan csoportosítjuk, akkor öt nagy csoport különíthető el: kavicsok (ép és törött), kavicseszközök, durva szilánkok, szilánkeszközök és magkőeszközök. Az öt csoport közül a magkövek aprólékos analízise járt a legnagyobb eredménnyel. A magkő használatának és szilánk leválasztásának sajátos tatai koncepcióját a 11. ábra illusztrálja. Egybevetve más kortárs mikrolitikus lelőhelyekkel ez az eszközmegmunkáló hagyomány nem függ össze a nyersanyag- gal. Ha nem is tudjuk pontosan meghatározni, de elvetni sem lehet a genetikai kapcsolatot a közép-európai alsópaleolit kavicsiparokkal, jelen esetben Vértesszőlőssel. A 2-3 sm-es tökéletes kőeszközök elkészítésének és használatának lehetéseges módjai egyrészt a neandertáliak magas szintú manuális készségéről, másrészt erdős környezetről/famegmunkálásról tanúskodnak. A dolgozat végén még néhány gondolat a középsőpaleolit közösségek mobilitásáról, vadászati stratégiájáról (az állatok által is gyakran felkeresett források környékét rendszeresen megszállták), módszereikról.

Tata és néhány kortárs lelőhely ipara az eltérő környezeti adottságok ellenére egy erős hagyományokban gyökerező, sajátos eszközkészítési koncepciót képvisel. 